\title{
Loopbanen na de Universiteit Maastricht: meting 2002
}

Citation for published version (APA):

van Eijs, P. W. L. J. (2002). Loopbanen na de Universiteit Maastricht: meting 2002. Researchcentrum voor Onderwijs en Arbeidsmarkt, Faculteit der Economische Wetenschappen. ROA Reports No. 17 https://doi.org/10.26481/umarep.2002017

Document status and date:

Published: 01/01/2002

DOI:

10.26481/umarep.2002017

Document Version:

Publisher's PDF, also known as Version of record

\section{Please check the document version of this publication:}

- A submitted manuscript is the version of the article upon submission and before peer-review. There can be important differences between the submitted version and the official published version of record.

People interested in the research are advised to contact the author for the final version of the publication, or visit the DOI to the publisher's website.

- The final author version and the galley proof are versions of the publication after peer review.

- The final published version features the final layout of the paper including the volume, issue and page numbers.

Link to publication

\footnotetext{
General rights rights.

- You may freely distribute the URL identifying the publication in the public portal. please follow below link for the End User Agreement:

www.umlib.nl/taverne-license

Take down policy

If you believe that this document breaches copyright please contact us at:

repository@maastrichtuniversity.nl

providing details and we will investigate your claim.
}

Copyright and moral rights for the publications made accessible in the public portal are retained by the authors and/or other copyright owners and it is a condition of accessing publications that users recognise and abide by the legal requirements associated with these

- Users may download and print one copy of any publication from the public portal for the purpose of private study or research.

- You may not further distribute the material or use it for any profit-making activity or commercial gain

If the publication is distributed under the terms of Article $25 \mathrm{fa}$ of the Dutch Copyright Act, indicated by the "Taverne" license above, 


\section{Loopbanen na de Universiteit Maastricht: meting 2002}

ROA-R-2002/17

Patrick van Eijs

Researchcentrum voor Onderwijs en Arbeidsmarkt

Faculteit der Economische Wetenschappen en Bedrijfskunde Universiteit Maastricht

Maastricht, December 2002 
ISBN 90-5321-352-X

Sec02.222.doc 


\section{Inhoud}

Bladzijde

Voorwoord

Resumé

1 Inleiding 1

1.1 Arbeidsmarktscanner Universiteit Maastricht 1

1.2 Onderzoekspopulatie 1

1.3 Centrale vraagstellingen en opbouw van het rapport 3

2 De huidige arbeidsmarktpositie 5

2.1 De maatschappelijke positie 5

2.2 De huidige baan 6

2.3 Een evaluatie van de baan en de studiekeuze 11

$\begin{array}{lll}2.4 \text { Conclusie } & 14\end{array}$

3 De loopbaan 17

3.1 Een retrospectieve kijk op loopbanen $\quad 17$

$\begin{array}{ll}3.2 \text { Individuele loopbaanpatronen } & 21\end{array}$

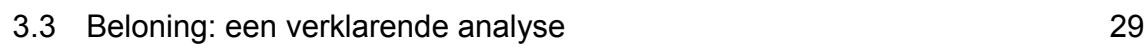

$\begin{array}{lll}3.4 & \text { Conclusie } & 32\end{array}$

4 De aansluiting tussen beroep en opleiding 35

4.1 De aansluiting tussen opleidingsrichting en beroep in kaart 35

4.2 De gevolgen van het werken buiten het eigen beroependomein 41

4.3 Conclusie 44 



\section{Voorwoord}

Het Researchcentrum voor Onderwijs en Arbeidsmarkt (ROA) verricht sinds 1990 periodiek onderzoek naar de arbeidsmarktintrede en vanaf 1998 ook periodiek onderzoek naar de loopbanen van alumni van de Universiteit Maastricht. Dit gebeurt in opdracht van het College van Bestuur. De Arbeidsmarktscanner van de Universiteit Maastricht (UM Scanner) is een langlopend project waarbij alumni circa anderhalf, vijf en tien jaar na afstuderen een schriftelijke vragenlijst ontvangen. Voor alumni die na anderhalf jaar een vragenlijst ontvangen, staat de arbeidsmarktintrede centraal. Met deze meting wordt inzicht verkregen in de overgang van studie naar werk. Bij de vragenlijsten die alumni vijf jaar en tien jaar na hun afstuderen ontvangen, staat het loopbaanverloop centraal.

De data van de UM Scanner maken een analyse van het loopbaanverloop op zowel de korte als de lange termijn mogelijk. In dit rapport worden de resultaten gepresenteerd van de in het najaar van 2001 gehouden meting onder alumni van de UM uit 1999/2000 (afstudeercohort 2000) en de in het voorjaar van 2002 gehouden metingen onder alumni uit 1990/1991 (afstudeercohort '91) circa tien jaar na afstuderen en alumni uit 1995/1996 (afstudeercohort '96) circa vijf jaar na afstuderen. Er heeft bovendien een koppeling plaatsgevonden tussen de verschillende metingen van het betreffende cohort, zodat ook longitudinale analyses mogelijk zijn.

De in het najaar van 2001 gehouden meting onder recent afgestudeerden heeft plaatsgevonden in het bredere kader van de WO-monitor. Dit is een in opdracht van de VSNU en de verschillende universiteiten uitgevoerd landelijk onderzoek onder afgestudeerden. Over deze WO-monitor wordt gerapporteerd in een landelijk rapport in opdracht van de VSNU. De in het voorjaar van 2001 gehouden loopbaanmetingen zijn in samenwerking met het Bureau Inschrijvingen van de Dienst Studentenzaken van de Universiteit Maastricht en DESAN Research Solutions uitgevoerd. Het ROA is verantwoordelijk geweest voor de methodologische en inhoudelijke aspecten van het project, de jaarlijkse rapportages en het beheer van de onderzoeksgegevens.

Bij het Bureau Inschrijvingen van de UM is aan het onderzoek meegewerkt door Werner Engels, Hans Smit en Simon Vogel. Bij DESAN Research Solutions hebben Monique van Alphen en Han van Dongen aan het onderzoek meegewerkt. Deze rapportage is samengesteld door drs. Patrick van Eijs. Verder is er bij het ROA aan het onderzoek meegewerkt door drs. Ger Ramaekers en Esther Soudant. Het project wordt intern begeleid door dr. Rolf van der Velden, hoofd van de afdeling Onderwijs en Beroepsloopbaan. 



\section{Resumé}

Het gaat de UM'er voor de wind

De arbeidsmarktpositie van de alumni van de Universiteit Maastricht is rooskleurig. De werkloosheid is laag. Alleen onder recent afgestudeerde alumni is er sprake van werkloosheid van enige betekenis, met name onder juristen (4 procent). De wat oudere alumnus verdwijnt wel steeds vaker uit het (betaalde) arbeidsproces. Van de groep die tien jaar geleden afstudeerde heeft 12 procent geen betaald werk en is ook niet actief op zoek naar werk. Vooral juristen en gezondheidswetenschappers kiezen voor een andere invulling. Ook beginnen steeds meer UM'ers een eigen bedrijf. Tien jaar na afstuderen verdient zo'n 10 procent als zelfstandige zijn brood. Het zijn vooral medici en juristen die hiervoor kiezen.

$\mathrm{Na}$ een aantal jaren weet zo'n 80 procent een vaste aanstelling te verwerven. Met name economen verwerven relatief snel een vaste baan. Na één jaar heeft driekwart van de economen een contract voor onbepaalde tijd verworven. Over het algemeen werken UM'ers in een functie waarvoor de werkgever een WO-opleiding vereist. Ongeveer driekwart van de alumni heeft een baan op WO-niveau. De verschillen tussen de faculteiten zijn aanzienlijk. Vrijwel alle medici hebben een baan op WOniveau verworven. Economen en gezondheidswetenschappers komen daarentegen relatief vaak in banen terecht waarvoor de werkgever niet expliciet een WO-diploma vereist. Het overgrote deel van de alumni (meer dan 75 procent) heeft een baan gevonden die goed aansluit op de opleidingsrichting die zij hebben gevolgd. De verschillen tussen de faculteiten zijn ook hier groot. Medici vinden opnieuw vrijwel allemaal een passende functie. De alumni van meer generieke opleidingen zoals Economie en Cultuur en Wetenschapsstudies komen daarentegen ook in banen terecht die minder goed aansluiten bij de gevolgde opleiding.

De mate waarin alumni leidinggeven aan collega's geeft een goede indicatie van de groei die tijdens een loopbaan wordt doorgemaakt. Het is niet verrassend dat naarmate de loopbaan vordert leidinggeven een steeds grotere rol gaat spelen. Van de UM'ers die pas één jaar geleden zijn afgestudeerd, werkt zo'n 20 procent in een leidinggevende functie. Voor alumni die reeds tien jaar geleden de UM hebben verlaten is dit percentage drie keer zo hoog. De verschillen tussen de faculteiten zijn relatief gering. Een tweede en erg in het oog springende indicator voor de groei is de beloning. Alumni uit het cohort 1990-1991 verdienen per uur bijna twee keer zoveel als net afgestudeerde UM'ers (respectievelijk $€ 24,45$ en $€ 13,09$ ). De beloning van economen en medici ontloopt elkaar nauwelijks. Het loon van juristen en (ondanks de wat hogere leeftijd) ook gezondheidswetenschappers blijft hierbij wat achter.

\section{Alumni zijn erg tevreden}

UM'ers hebben een hoge werksatisfactie. Zo'n 80 procent van de Maastrichtse alumni geeft aan (zeer) tevreden te zijn met de huidige baan. De verschillen tussen de faculteiten en de cohorten zijn over het algemeen gering. Medici zijn het meest 
tevreden. Bijna 90 procent geeft aan (zeer) tevreden te zijn met de huidige baan. Dit is niet verrassend gezien het specifieke karakter van de opleiding, het duidelijke beroepsbeeld en de goede aansluiting tussen beroep en opleiding. Bovendien voldoet de huidige werksituatie aan de verwachtingen aan het begin van de studie. Minder dan 10 procent van de alumni geeft aan dat de huidige situatie (veel) slechter is dan verwacht.

Zo'n driekwart van de alumni geeft, achteraf terugkijkend, aan dat ze opnieuw voor dezelfde studie aan de UM gekozen zouden hebben. Dit percentage is het hoogst voor de economen en de medici. Voor alle cohorten geldt dat meer dan 80 procent van de medici en economen opnieuw voor dezelfde studie aan de UM zouden kiezen. Over het algemeen zouden weinig Maastrichtse alumni dezelfde opleiding aan een andere universiteit hebben willen volgen. Minder dan $20 \%$ zou voor een andere WO-opleiding gekozen hebben. Vooral gezondheidswetenschappers geven aan spijt te hebben van hun keuze. Geneeskunde en psychologie zijn veel genoemde alternatieven.

\section{Een moeizame start van de loopbaan heeft gevolgen}

Een start van de loopbaan beneden WO-niveau leidt er relatief vaak toe dat alumni ook later beneden WO-niveau werkzaam zijn. Ruim de helft (52 procent) van de alumni uit het cohort 1995-1996 die beneden WO-niveau startten, werkt na vijf jaar nog steeds beneden zijn of haar niveau. Voor het cohort 1990-1991 blijkt onderbenutting ook na tien jaar een hardnekkig fenomeen te zijn. Alumni die na één jaar beneden WO-niveau werkzaam waren, zijn na tien jaar nog steeds relatief vaak onder hun niveau werkzaam (45 procent). Vooral economen en gezondheidswetenschappers zijn hiervoor verantwoordelijk. Ook ten aanzien van de aansluiting naar richting heeft de start grote gevolgen voor de rest van de loopbaan. Meer dan de helft van degenen die buiten het eigen beroependomein startten is na vijf jaar ook buiten het domein werkzaam. Van de groep die na één jaar een baan had verworven die qua richting goed aansloot bij de opleiding is na vijf jaar maar 15 procent uitgeweken naar een baan buiten het eigen domein. Verder zien we dat tussen de vijf en tien jaar na afstuderen het aandeel van alumni dat buiten het eigen domein werkt nauwelijks meer verandert. De verschillen tussen de faculteiten zijn opmerkelijk gering, met uitzondering van de faculteit Geneeskunde waarvan de alumni vrijwel allemaal binnen hun eigen richting starten en gedurende het vervolg van hun loopbaan werkzaam blijven.

Alumni starten relatief vaak in een tijdelijke baan. Na vijf jaar blijkt zo'n start in een tijdelijke baan nog steeds merkbaar. Van degenen uit het cohort 1995-1996 die na één jaar een vaste baan hadden verworven, werkt na vijf jaar slechts 7 procent met een tijdelijk contract. Voor degenen die na één jaar een tijdelijke aanstelling hadden, is dit meer dan 20 procent. Voor het cohort 1990-1991 is dit effect nog beter zichtbaar. $\mathrm{Na}$ vijf jaar heeft slechts 59 procent van de alumni die na één jaar een tijdelijk contract hadden, een vaste baan verworven. Medici zijn voor een belangrijk deel verantwoordelijk voor het effect van een geringe baanzekerheid na één jaar op het al dan niet hebben van een vast contract na vijf jaar. Bij de juristen, economen en 
gezondheidswetenschappers is het effect weliswaar aanwezig, maar veel kleiner. Geconcludeerd kan worden dat over het algemeen slechts een kleine groep de gevolgen van een geringe baanzekerheid aan het begin van de loopbaan na vijf jaar nog steeds ondervindt. Bovendien blijkt dit effect na tien jaar volledig te zijn verdwenen. Meer dan 80 procent van de alumni heeft een vaste baan, ongeacht de baanzekerheid in de loopbaan tot dan toe.

Het startloon blijkt een goede voorspeller voor de latere loonontwikkeling

De beloning is een goede indicator om te illustreren welke groei alumni tijdens hun loopbaan doormaken. Voor het cohort 1995-1996 zijn in de periode tussen één en vijf jaar na afstuderen de lonen met maar liefst bijna 90 procent gestegen. Voor de economen zijn de lonen zelfs verdubbeld. Voor de medici en de gezondheidswetenschappers was de stijging het kleinst met respectievelijk 68 en 72 procent. Voor het cohort 1990-1991 was de loonstijging in de eerste fase van de loopbaan veel bescheidener, vanwege de geringere inflatie en de minder krappe arbeidsmarkt voor hoger opgeleiden in de eerste helft van de jaren negentig. Ook voor het cohort 1990-1991 zijn de lonen echter enorm gestegen gedurende de afgelopen vijf jaar. Uiteindelijk verdienen alumni na tien jaar ruim 120 procent meer dan één jaar na afstuderen. Gecorrigeerd voor de inflatie is dit een reële stijging van zo'n 90 procent. De lonen van economen zijn het meest gestegen: 157 procent. Medici en juristen zijn twee keer zoveel gaan verdienen.

De start van de loopbaan blijkt een significant effect te hebben op het loopbaansucces. Uit een verklarende loonanalyse blijkt dat het loon één jaar na afstuderen een belangrijk significant effect heeft op de beloning na vijf jaar. Met andere woorden: een hoge beloning aan het begin van de loopbaan heeft een belangrijke voorspellende waarde voor de groei van het loon in de daarop volgende vier jaar. Dit wil overigens niet zeggen dat er sprake is van een causaal verband. Het effect kan ook worden toegeschreven aan het feit dat zowel het loon na één als na vijf jaar door dezelfde (ongemeten) achtergrondfactoren worden bepaald.

Naast de beloning heeft ook de aansluiting één jaar na afstuderen een significant effect op het loon na vijf jaar. Dit betekent dat een functie op WO-niveau tijdens de start van de loopbaan een succesvolle verdere loopbaan bevordert. Omgekeerd heeft een start in een functie beneden WO-niveau - ook wanneer na vijf jaar inmiddels een functie op WO-niveau is verworven - nog altijd een effect op het loon. De werkgever waardeert blijkbaar de werkervaring die is opgedaan op academisch niveau. Daarnaast is ook het effect van het werken op WO-niveau na vijf jaar significant. Dit impliceert dat niet alleen de start in een academische functie loont. Ook tussen één en vijf jaar na afstuderen wordt het emplooi vinden in een baan op WO-niveau beloond met een grotere loonstijging dan wanneer de UM'er werkzaam is in een baan onder zijn of haar niveau. 
De loopbaanpatronen van mannen en vrouwen verschillen. Dit komt met name tot uiting in het in deeltijd werken. Voor het cohort 1995-1996 geldt dat bijna de helft van degenen die na één jaar parttime werkten, dat na vijf jaar nog steeds doet. Van de groep die na één jaar een volledige aanstelling had, werkt slechts 21 procent in deeltijd. Het cohort 1990-1991 laat zien dat ook na tien jaar weinig is veranderd. Bijna de helft (47 procent) van de alumni die na één jaar in deeltijd werkten, doet dat na tien jaar ook. Deze groep wordt zelfs in de loop der jaren weer groter. Na vijf jaar blijkt namelijk tweederde van de parttime starters fulltime te werken. Zo'n 15 procent van de parttime starters komt dus tussen de vijf en tien jaar na afstuderen opnieuw in een parttime baan terecht. De verschillen tussen mannen en vrouwen zijn groot. Daar waar mannen, ook wanneer ze in een parttime baan gestart zijn, na vijf en tien jaar meest een volledige werkweek hebben, kiezen vrouwen veel vaker voor een parttime aanstelling. $\mathrm{Na}$ tien jaar is het verschil tussen vrouwelijke parttime en fulltime starters relatief klein geworden. Dit wijst erop dat vrouwen - vooral vanwege de zorg voor kinderen - vrijwillig kiezen voor een parttime baan.

Ook zijn er verschillen in de beloning. Bij de start van de loopbaan verdienen vrouwen gemiddeld genomen minder dan mannen. Vrouwen maken een inhaalslag gedurende de loopbaan; het uurloon van vrouwen stijgt sneller dan dat van mannen. Deze inhaalslag van vrouwen betekent niet dat ze (absoluut gezien) hun achterstand op mannen inhalen. Het verschil wordt echter niet groter: mannen blijken na tien jaar, net als na één jaar, ongeveer $€ 1$,- bruto per uur meer te verdienen dan vrouwen.

\section{Werken buiten eigen richting is een reële optie}

Een loopbaanpad dat afwijkt van het 'reguliere' pad kan een goede optie zijn voor de alumni van de UM. Zo zien we dat UM'ers steeds vaker buiten de eigen richting gaan werken naarmate de loopbaan vordert. Na één jaar is 10 procent van de UM'ers buiten de eigen richting werkzaam; na vijf jaar is dit gestegen tot 16 procent. Deze toename doet zich bij alle faculteiten voor. Tien procent van de alumni blijkt na een start binnen het eigen domein te kiezen voor een baan waarvoor de werkgever niet expliciet de eigen of een verwante opleiding vereist. De groei van het aantal UM'ers dat, naarmate de loopbaan vordert, buiten de eigen richting werkzaam is moet vooral gezocht worden bij deze groep. Weliswaar is er een groep die vanaf de start van de loopbaan emplooi vindt buiten het eigen domein. Van deze groep keert echter meer dan de helft terug naar een baan binnen de eigen vakrichting.

Veel UM'ers lijken een positieve keuze te maken voor een baan buiten het eigen vakgebied. Zo zijn het vaak inhoudelijke factoren die tot deze keuze hebben geleid. Bijna 40 procent geeft aan liever buiten het eigen vakgebied te werken. Daarnaast geeft 16 procent aan het werk buiten het eigen vakgebied ook interessant te vinden. Een tweede belangrijk element wordt gevormd door factoren die te maken hebben met de arbeidsmarktpositie. Met name de betere carrièremogelijkheden (26 procent) worden hier vaak genoemd. Het niet kunnen vinden van een passende baan is daarentegen slechts voor 13 procent een bepalende factor. UM'ers komen daarbij 
relatief vaak in min of meer verwante beroepen terecht. De econoom wordt bijvoorbeeld commercieel medewerker en de gezondheidswetenschapper wordt (of blijft) therapeut of verpleegkundige. Daarnaast biedt de ICT-sector voor de UM'er een mogelijkheid zijn horizon te verbreden. Ook komen UM'ers na vijf jaar in managementfuncties terecht.

Ten slotte blijkt er weinig verschil te zijn in werksatisfactie tussen UM'ers die binnen en buiten hun eigen vakrichting werkzaam zijn. Van degenen die binnen het eigen domein emplooi hebben gevonden, is 84 procent (zeer) tevreden met de huidige baan. Buiten het eigen domein is dit zelfs 88 procent. Dit beeld is bij alle faculteiten terug te vinden. Daarnaast is het aantal UM'ers dat buiten zijn eigen richting werkzaam is en daarbij teleurgesteld is over zijn werksituatie te verwaarlozen. Deze tevredenheid kan misschien wel gezien worden als de meest krachtige aanwijzing dat het afwijken van het reguliere loopbaanpad een reële optie is voor UM'ers. 



\section{$1 \quad$ Inleiding}

\subsection{Arbeidsmarktscanner Universiteit Maastricht}

In opdracht van de Universiteit Maastricht (UM) verricht het Researchcentrum voor Onderwijs en Arbeidsmarkt (ROA) in samenwerking met de Dienst Studentzaken sinds 1990 periodiek onderzoek onder alumni van de UM met behulp van de zogenaamde UM scanner. Deze Arbeidsmarktscanner van de Universiteit Maastricht is een langlopend project waarbij alumni zowel anderhalf jaar, vijf jaar als tien jaar na afstuderen een schriftelijke vragenlijst ontvangen. Daarin wordt gevraagd naar hun arbeidsmarktintrede, loopbaanverloop en huidige arbeidsmarktpositie. Ook gaat de vragenlijst in op diverse onderwerpen zoals de aansluiting van studie op werk, werkoriëntaties en het volgen van verdere opleidingen. Er wordt op uiteenlopende manieren over de bevindingen gerapporteerd. Zo wordt onder meer voor het College van Bestuur een Management Summary gemaakt en ontvangen de afzonderlijke faculteiten elk een faculteitsrapportage. Daarnaast worden de resultaten uit de meting anderhalf jaar na afstuderen gebruikt in een landelijke onderzoek, de zogenaamde WO-monitor. Over deze WO-monitor wordt gerapporteerd in een landelijk rapport in opdracht van de VSNU.

De drie vragenlijsten die jaarlijks worden afgenomen verschillen van elkaar, afhankelijk van het tijdstip van de meting. Voor afgestudeerden die na anderhalf jaar een vragenlijst ontvangen, staat de arbeidsmarktintrede centraal. Met deze meting wordt meer inzicht verkregen in de overgang van de Universiteit Maastricht naar de arbeidsmarkt. Zo worden onder meer vragen gesteld over de vooropleiding, de afgesloten opleiding, eventuele bestuurs- en werkervaring voor het afstuderen, de activiteiten na het afstuderen en de huidige situatie. De vragenlijsten die alumni vijf en tien jaar na hun afstuderen ontvangen, bevatten deze vragen ook. In deze vragenlijsten staat echter het loopbaanverloop centraal. Er worden vragen gesteld die meer inzicht geven in de loopbaanontwikkeling van de alumni, zoals bijvoorbeeld het aantal banen dat men heeft gehad en de functieveranderingen bij een bepaalde werkgever.

De data van de UM scanner maken een analyse van het loopbaanverloop op zowel korte als lange termijn mogelijk. Dit rapport gaat in op de transitie van universiteit naar arbeidsmarkt en de loopbaan van alumni uit 1999-2000 (afstudeercohort 2000), 1995-1996 (afstudeercohort 1996) en 1990-1991 (afstudeercohort 1991). Er heeft bovendien een koppeling plaatsgevonden tussen de verschillende metingen van het betreffende cohort, zodat ook longitudinale analyses mogelijk zijn.

\subsection{Onderzoekspopulatie}

Het cohort 1999-2000 heeft in het najaar van 2001 een vragenlijst ontvangen. De cohorten 1990-1991 en 1995-1996 zijn in het voorjaar van 2002 benaderd. In tabel 1.1 wordt een overzicht gegeven van de respons. Verschillende factoren bepalen de respons. We zien bijvoorbeeld dat de respons in de loop der jaren langzaam 
afneemt. Een tweede factor is de actualiteit van het adressenbestand. Dit bestand is met name voor de oudere cohorten niet meer optimaal. Het achterhalen van alumni die jaren geleden zijn afgestudeerd is niet eenvoudig. Een derde factor is de internationalisering. Het toenemende internationale karakter van de Universiteit Maastricht leidt ertoe dat alumni in toenemende mate in het buitenland terechtkomen. Dit maakt het achterhalen van de alumni nog gecompliceerder.

Tabel 1.1

Responscijfers recente metingen

\begin{tabular}{|c|c|c|c|c|c|c|}
\hline & \multicolumn{2}{|c|}{ Cohort 1990-1991 } & \multicolumn{2}{|c|}{ Cohort 1995-1996 } & \multicolumn{2}{|c|}{ Cohort 1999-2000 } \\
\hline & $\begin{array}{l}\text { Aantal } \\
\text { alumni }\end{array}$ & $\begin{array}{c}\text { Respons } \\
\%\end{array}$ & $\begin{array}{l}\text { Aantal } \\
\text { alumni }\end{array}$ & $\begin{array}{c}\text { Respons } \\
\%\end{array}$ & $\begin{array}{l}\text { Aantal } \\
\text { alumni }\end{array}$ & $\begin{array}{c}\text { Respons } \\
\%\end{array}$ \\
\hline FdAW & & & 2 & 0 & 19 & 42 \\
\hline $\mathrm{FdCW}$ & & & 30 & 57 & 46 & 52 \\
\hline FdEWB & 93 & 37 & 416 & 49 & 378 & 37 \\
\hline $\mathrm{FdG}$ & 126 & 39 & 136 & 54 & 145 & 48 \\
\hline FdGW & 243 & 40 & 426 & 43 & 355 & 60 \\
\hline $\mathrm{FdP}$ & & & & & 61 & 56 \\
\hline $\mathrm{FdR}$ & 162 & 29 & 330 & 31 & 256 & 49 \\
\hline Totaal & 624 & 37 & 1342 & 42 & 1260 & 48 \\
\hline
\end{tabular}

Bron: ROA

Uit tabel 1.1 blijkt dat de respons voor het cohort 1999-2000 bijna 50 procent bedraagt. Met name onder de gezondheidswetenschappers en de psychologen is de respons hoog. De economen blijven hier duidelijk bij achter. Voor de cohorten 19901991 en 1995-1996 ligt de respons met respectievelijk 37 en 42 procent wat lager. De verschillen tussen de faculteiten zijn over het algemeen niet zo groot. Alleen de juristen springen er enigszins in negatieve zin uit.

Tabel 1.2

Responscijfers gekoppelde bestanden

\begin{tabular}{|c|c|c|c|c|}
\hline & \multicolumn{2}{|c|}{ Cohort 1990-1991 } & \multicolumn{2}{|c|}{ Cohort 1995-1996 } \\
\hline & Aantal alumni & Respons \% & Aantal alumni & Respons \% \\
\hline $\mathrm{FdCW}$ & & & 30 & 40 \\
\hline FdEWB & 93 & 27 & 416 & 34 \\
\hline FdG & 126 & 35 & 136 & 42 \\
\hline FdGW & 243 & 38 & 426 & 30 \\
\hline FdR & 162 & 24 & 330 & 21 \\
\hline Totaal & 624 & 32 & 1342 & 30 \\
\hline
\end{tabular}

Bron: ROA

Daarnaast wordt er in dit rapport gebruik gemaakt van twee gekoppelde bestanden. Voor het cohort 1995-1996 zijn de resultaten van de meting anderhalf jaar na afstuderen in 1997 en de meting vijf jaar na afstuderen in 2002 aan elkaar gekoppeld. Voor het cohort 1990-1991 zijn de resultaten van de metingen in 1992, 1997 en 2002 aan elkaar gekoppeld. Tabel 1.2 laat de responscijfers voor de 
gekoppelde bestanden zien. In feite betreft hier het percentage alumni dat beide, respectievelijk alle drie de vragenlijsten heeft ingevuld.

\subsection{Centrale vraagstellingen en opbouw van het rapport}

De UM scanner bevat een schat aan gegevens die gebruikt kunnen worden voor wetenschappelijk loopbaanonderzoek. Het uitvoeren van een dergelijk onderzoek heeft als toegevoegde waarde dat er niet alleen beschrijvingen kunnen worden gegeven van hoe het de alumni vergaat. Er kan tevens worden stilgestaan bij de vraag waarom het alumni vergaat zoals ze het vergaat. In het kader hiervan staat in dit rapport zowel een beschrijving van de huidige (arbeidsmarkt)situatie als een beschrijving van de loopbaan van Maastrichtse alumni centraal. Er wordt daarbij zowel op cross-sectionele als longitudinale wijze naar loopbanen gekeken. Twee vragen staan centraal:

1. Hoe vergaat het alumni van de Universiteit Maastricht in de verschillende fasen van hun loopbaan?

2. Welke factoren zijn mogelijk van invloed op een succesvolle loopbaan?

Het rapport is als volgt opgebouwd. Hoofdstuk 2 is gericht op het in kaart brengen van de huidige (arbeidsmarkt)situatie van de alumni van de Universiteit Maastricht. Er wordt onder meer aandacht geschonken aan de maatschappelijke positie, de huidige baan en de mate van tevredenheid met de huidige situatie. Hiermee is hoofdstuk 2 vooral gericht op de vraag hoe het de Maastrichtse alumni in de verschillende fasen van hun loopbaan thans vergaat. In hoofdstuk 2 wordt gekozen voor de cross-sectionele aanpak.

Hoofdstuk 3 gaat dieper in op de loopbanen van de Maastrichtse alumni. Er zal worden gekeken naar loopbaanpatronen en de ontwikkeling in de arbeidsmarktpositie. Het hoofdstuk spitst zich daarbij uiteindelijk toe op twee vragen. Op de eerste plaats wordt gekeken naar het effect van de start van de loopbaan op het loopbaansucces. Heeft een moeizame start gevolgen op de langere termijn? Of weten 'langzame' starters de achterstand in te halen? Op de tweede plaats wordt gekeken naar het effect van persoonlijke factoren en elementen uit de schoolloopbaan op de langere termijn. Persoonskenmerken die de revue zullen passeren zijn bijvoorbeeld de gezinssamenstelling, het geslacht en de leeftijd. Schoolprestaties en gevolgde opleiding zijn elementen uit de schoolloopbaan waarvan de impact op de loopbaan onder de loep wordt genomen. In hoofdstuk 3 wordt gekozen voor de longitudinale aanpak, waarmee ontwikkelingen in de loopbaan ook in hun onderlinge samenhang kunnen worden bekeken. Deze longitudinale aanpak biedt de mogelijkheid de dynamiek die aan deze processen ten grondslag ligt in kaart te brengen. Zo kan de longitudinale aanpak blootleggen dat niet alleen alumni met een voortvarende start een succesvolle loopbaan kunnen opbouwen, maar dat ook na een moeizame start een succesvolle loopbaan in het verschiet kan liggen.

Hoofdstuk 4 heeft een thematisch karakter. De relatie tussen opleiding en beroep en de daaraan nauw gerelateerde aansluitingsproblematiek staan in dit hoofdstuk centraal. In het onderzoek naar de transitie van school naar werk ligt de nadruk op 
de gevolgen van een minder goede aansluiting voor het functioneren in de baan. Hierbij wordt er impliciet vanuit gegaan dat de afgestudeerde beter zal functioneren in een baan die inhoudelijk goed aansluit bij de in de opleiding verworven kennis en vaardigheden. Met andere woorden: de mate waarin alumni in staat zijn een baan te vinden te goed aansluit op de opleiding, vormt een goede indicator voor een succesvolle start van de loopbaan. De vraag is hoe dit beeld er later in de loopbaan uitziet. Is een goede inhoudelijke aansluiting tussen opleiding en beroep nog steeds zo belangrijk als bij de start op de arbeidsmarkt? Of kan een loopbaanpad dat afwijkt van het 'reguliere' pad ook een goede optie zijn? Ook in dit hoofdstuk maakt de longitudinale aanpak het mogelijk de dynamiek in de relatie tussen opleiding en beroep te laten zien. 


\section{De huidige arbeidsmarktpositie}

In dit hoofdstuk zal uitgebreid aandacht worden besteed aan de huidige arbeidsmarktpositie van alumni van de Universiteit Maastricht. Ook dit jaar is aan drie groepen UM'ers een vragenlijst voorgelegd. Voor de groep die zo'n anderhalf jaar geleden is afgestudeerd geldt dat de transitie van universiteit naar arbeidsmarkt min of meer achter de rug is. De arbeidsmarktpositie van deze groep geeft daarmee een antwoord op de vraag in hoeverre de opleiding aan de universiteit Maastricht de afgestudeerde de mogelijkheid biedt een goede start op de arbeidsmarkt te maken. Ook vijf en tien jaar na afstuderen wordt de arbeidsmarktsituatie in kaart gebracht. $\mathrm{Na}$ vijf jaar krijgen loopbanen een definitief karakter. Na tien jaar heeft de loopbaan min of meer zijn hoogtepunt bereikt.

De opzet van dit hoofdstuk is als volgt. De eerste paragraaf gaat kort in op de huidige maatschappelijke positie. Het gaat hierbij om aspecten als het al dan niet hebben van werk, e.d. Paragraaf 2.2 gaat dieper in op de huidige baan. Paragraaf 2.3 heeft een meer evaluerend karakter. In hoeverre zijn Maastrichtse alumni tevreden met de huidige situatie? Zouden ze opnieuw voor dezelfde studie kiezen?

Bij het vergelijken van alumni uit verschillende lichtingen en verschillende fasen van de loopbaan dient te worden gewezen op zogenaamde cohorteffecten. Zo was de arbeidsmarktsituatie tien jaar geleden veel ongunstiger dan de afgelopen jaren. Dit heeft niet alleen effect op al dan niet glad verlopen van de transitie van universiteit naar arbeidsmarkt. Mogelijk heeft een minder goede start gevolgen voor de latere loopbaan (in hoofdstuk 3 zal aan het effect van een moeizame start op de loopbaan aandacht worden geschonken).

\subsection{De maatschappelijke positie}

In de tabellen 2.1a tot en met 2.1c wordt de maatschappelijke positie gepresenteerd van de alumni in de verschillende cohorten. Er is aan de respondenten gevraagd om zelf hun huidige situatie te typeren. Het betreft hier dus een eigen inschatting van de belangrijkste bezigheden. Met name bij de categorie werkloos dient onderstreept te worden dat het om een subjectieve inschatting gaat.

Tabel 2.1a

Maatschappelijke positie na één jaar in procenten, cohort 1999-2000, 2002

\begin{tabular}{lrrrrrrr}
\hline & FdCW & FdEWB & FdG & FdGW & FdP & FdR & Totaal \\
\hline Betaald werk & 96 & 93 & 92 & 89 & 97 & 91 & 92 \\
Studie & 0 & 4 & 3 & 6 & 0 & 2 & 4 \\
Werkloos & 0 & 2 & 2 & 1 & 0 & 4 & 2 \\
Anders & 4 & 3 & 3 & 3 & 3 & 3 & 3 \\
\hline Bron: ROA & & & & & & &
\end{tabular}


Tabel $2.1 b$

Maatschappelijke positie na vijf jaar in procenten, cohort 1995-1996, 2002

\begin{tabular}{lrrrrrr}
\hline & FdCW & FdEWB & FdG & FdGW & FdR & Totaal \\
\hline Betaald werk & 80 & 97 & 78 & 93 & 93 & 92 \\
Studie & 0 & 0 & 2 & 0 & 0 & 0 \\
Werkloos & 20 & 1 & 2 & 0 & 2 & 1 \\
Anders & 0 & 3 & 19 & 7 & 5 & 7
\end{tabular}

Bron: ROA

Tabel 2.1c

Maatschappelijke positie na tien jaar in procenten, cohort 1990-1991, 2002

\begin{tabular}{lrrrrr}
\hline & FdEWB & FdG & FdGW & FdR & Totaal \\
\hline Betaald werk & 94 & 94 & 83 & 80 & 86 \\
Studie & 0 & 2 & 0 & 0 & 0 \\
Werkloos & 0 & 0 & 3 & 0 & 1 \\
Anders & 6 & 4 & 14 & 20 & 12 \\
& & & & &
\end{tabular}

Bron: ROA

Het overgrote deel van de alumni heeft in 2002 een betaalde baan. Na één en vijf jaar is dit meer dan $90 \%$. Voor alumni die tien jaar geleden de universiteit hebben verlaten is dit percentage iets lager: $86 \%$. Dit verschil wordt vooral veroorzaakt door het groter aantal alumni dat noch een baan heeft, noch studeert en noch op zoek is naar een baan. Met name onder de gezondheidswetenschappers en de juristen is deze groep relatief groot. Het betreft hier onder meer Maastrichtse alumni die vanwege de zorg voor kinderen de arbeidsmarkt hebben verlaten.

\subsection{De huidige baan}

In paragraaf 2.1 hebben we gezien dat het overgrote deel van de alumni van de UM betaald werk heeft. In deze paragraaf wordt dieper ingegaan op dit werk. In de tabellen 2.2a tot en met 2.2c wordt een overzicht gegeven van het soort dienstverband. De tabellen laten zien dat meer dan $80 \%$ van de alumni in loondienst werkzaam is. Het aantal zelfstandigen is groter in de cohorten die de universiteit vijf en vooral tien jaar geleden hebben verlaten. Eén jaar na afstuderen is het aantal zelfstandigen nog te verwaarlozen; van de groep die tien jaar geleden is afgestudeerd is 10 procent eigen baas. Het zijn vooral medici en juristen die als zelfstandige werkzaam zijn. Het aantal zelfstandig opererende economen is opvallend laag. Vanzelfsprekend zijn alumni vooral aan het begin van hun loopbaan als AIO werkzaam. Het gaat hier vooral om psychologen, medici en gezondheidswetenschappers. Onder economen en juristen is het aantal AIO's gering. De uitzendmarkt is voor alumni van de UM over het algemeen van marginale betekenis. Een gering aantal alumni is als uitzendkracht werkzaam. De faculteit Cultuur en Wetenschapsstudies vormt hierop een uitzondering. Zo is bijna 10 procent van de alumni van deze faculteit na één jaar als uitzendkracht werkzaam.

6 
Tabel 2.2a

Dienstverband na één jaar in procenten, cohort 1999-2000, 2002

\begin{tabular}{lrrrrrrr}
\hline & FdCW & FdEWB & FdG & FdGW & FdP & FdR & Totaal \\
\hline AlO & 9 & 3 & 12 & 17 & 42 & 2 & 12 \\
Uitzendkracht & 9 & 1 & 0 & 1 & 6 & 7 & 3 \\
Loondienst & 78 & 92 & 77 & 79 & 52 & 86 & 81 \\
Zelfstandige & 0 & 0 & 0 & 0 & 0 & 1 & 0 \\
Anders & 4 & 5 & 11 & 3 & 0 & 5 & 4 \\
& & & & & & &
\end{tabular}

Bron: ROA

Tabel 2.2b

Dienstverband na vijf jaar in procenten, cohort 1995-1996, 2002

\begin{tabular}{lrrrrrr}
\hline & FdCW & FdEWB & FdG & FdGW & FdR & Totaal \\
\hline AlO & 7 & 1 & 6 & 2 & 0 & 2 \\
Uitzendkracht & 7 & 0 & 0 & 0 & 0 & 0 \\
Loondienst & 71 & 92 & 64 & 90 & 92 & 87 \\
Zelfstandige & 7 & 4 & 12 & 3 & 6 & 5 \\
Anders & 7 & 2 & 19 & 5 & 2 & 5 \\
\hline
\end{tabular}

Bron: ROA

Tabel $2.2 c$

Dienstverband na tien jaar in procenten, cohort 1990-1991, 2002

\begin{tabular}{lrrrrr}
\hline & FdEWB & FdG & FdGW & FdR & Totaal \\
\hline AlO & 0 & 0 & 0 & 0 & 0 \\
Uitzendkracht & 0 & 2 & 2 & 0 & 1 \\
Loondienst & 94 & 72 & 89 & 81 & 84 \\
Zelfstandige & 6 & 21 & 5 & 14 & 10 \\
Anders & 0 & 4 & 5 & 5 & 2 \\
\hline
\end{tabular}

Bron: ROA

Tabel 2.3

Vaste aanstelling in procenten per afstudeercohort, 2002

\begin{tabular}{lccccccc}
\hline & FdCW & FdEWB & FdG & FdGW & FdP & FdR & Totaal \\
\hline $1999-2000$ & 39 & 74 & 23 & 53 & 24 & 40 & 50 \\
$1995-1995$ & 54 & 92 & 47 & 79 & n.v.t. & 93 & 82 \\
$1990-1991$ & n.v.t. & 90 & 63 & 84 & n.v.t. & 92 & 83 \\
\hline
\end{tabular}

Bron: ROA

De baanzekerheid is een belangrijke indicator voor de arbeidsmarktpositie. Tabel 2.3 laat zien dat naarmate de loopbaan vordert steeds meer alumni een vaste aanstelling verwerven. Met name de periode tussen één en vijf jaar na afstuderen blijkt hierbij 
van groot belang. Na één jaar heeft de helft van de alumni een vaste aanstelling, terwijl meer dan 80 procent van degenen die vijf jaar geleden zijn afgestudeerd een vaste baan heeft. Opvallend is dat vooral economen al snel een vaste aanstelling verwerven. Na één jaar heeft al bijna driekwart van de economen een vaste baan. Met name de medici blijven hierbij ver achter. Hierbij dient echter in het oog te worden gehouden dat basisartsen vaak doorstromen naar een opleidingsplaats voor medisch specialist. Ook alumni van de faculteit Cultuur en Wetenschapsstudies ondervinden relatief veel moeite bij het vinden van een vaste baan.

In tabel 2.4 wordt een overzicht gegeven van het belang van parttime werk in de verschillende stadia van de loopbaan. Een parttime baan is hierbij gedefinieerd als een baan van 32 uur of minder. Uit de tabel blijkt dat het belang van parttime werk toeneemt naarmate men de opleiding langer geleden heeft verlaten. Na één jaar werkt éénvijfde van de alumni in deeltijd; na tien jaar is dit opgelopen tot meer dan 30 procent. De verschillen tussen de opleidingen zijn echter groot. Deeltijdwerk is voor economen een relatief zeldzaam fenomeen. Minder dan tien procent heeft een parttime baan. Dit percentage is bovendien stabiel over de verschillende stadia van de loopbaan. Medici die vijf of tien jaar geleden zijn afgestudeerd werken daarentegen veel vaker in deeltijd dan net afgestudeerde geneeskundigen. Voor gezondheidswetenschappers is het percentage deeltijders zelfs kort na het verlaten van de opleiding al uitzonderlijk hoog (35\%). Twee factoren spelen hierbij een rol. In de eerste plaats kennen de opleidingen Geneeskunde en Gezondheidswetenschappen veel vrouwelijke alumni. In de tweede plaats zijn de gezondheidswetenschappers gemiddeld ouder dan de alumni van de andere opleidingen. Zo is bijna 30 procent van de gezondheidswetenschappers één jaar na afstuderen 30 jaar of ouder, terwijl dit bij de economen nog geen 3 procent is.

Tabel 2.4

Parttime werk in procenten per afstudeercohort, 2002

\begin{tabular}{lccccccc}
\hline & FdCW & FdEWB & FdG & FdGW & FdP & FdR & Totaal \\
\hline $1999-2000$ & 13 & 9 & 8 & 35 & 18 & 10 & 20 \\
$1995-1995$ & 18 & 9 & 30 & 39 & n.v.t. & 16 & 23 \\
$1990-1991$ & n.v.t. & 9 & 33 & 45 & n.v.t. & 17 & 31 \\
\hline & & & & & & &
\end{tabular}

Bron: ROA

De tabellen 2.5, 2.6 en 2.7 gaan dieper in op de aansluiting tussen opleiding en werk. De aansluiting wordt vanuit twee invalshoeken bekeken. In de eerste plaats de aansluiting naar niveau. Het gaat hierbij om de vraag welk opleidingsniveau door de werkgever werd vereist. In de tweede plaats wordt gekeken naar de aansluiting naar richting. Het gaat hierbij om de vraag in hoeverre er door de werkgever gevraagd werd naar de eigen (of een verwante) opleiding.

In tabel 2.5 wordt aandacht geschonken aan de aansluiting naar niveau. De kwaliteit van de aansluiting naar niveau is een belangrijke indicator voor het loopbaansucces, Vanuit arbeidsmarktoogpunt kan worden gesteld dat hoe beter de aansluiting, hoe 
succesvoller de loopbaan. Uit de tabel blijkt dat ongeveer driekwart van de alumni een baan op WO-niveau heeft verworven. Voor de net afgestudeerden is dit percentage iets lager (70); voor de alumni uit het cohort 1990-1991 iets hoger (80). Dit verschil is niet verwonderlijk, aangezien alumni mogelijk aanvankelijk geen passende baan weten te verwerven, maar hier later in de loopbaan wel in slagen. De verschillen tussen de faculteiten zijn aanzienlijk. Vrijwel alle medici hebben een baan op WO-niveau verworven. Economen komen daarentegen relatief vaak in banen terecht waarvoor de werkgever niet expliciet een WO-diploma vereist. Vooral voor adviseursfuncties nemen werkgevers ook met een HBO-diploma genoegen. Ook gezondheidswetenschappers werken vaak op HBO-niveau of lager. Het feit dat gezondheidswetenschappers vaak reeds ervaring hebben opgedaan in bijvoorbeeld de verpleging en ook vaak na het afronden van de academische studie in hun vakgebied werkzaam blijven, speelt hierbij echter een belangrijke rol.

Tabel 2.5

Werk op WO-niveau in procenten per afstudeercohort, 2002

\begin{tabular}{lccccccc}
\hline & FdCW & FdEWB & FdG & FdGW & FdP & FdR & Totaal \\
\hline & & & & & & & \\
$1999-2000$ & 61 & 61 & 99 & 61 & 88 & 77 & 70 \\
$1995-1995$ & 77 & 61 & 99 & 64 & n.v.t. & 81 & 71 \\
$1990-1991$ & n.v.t. & 82 & 100 & 72 & n.v.t. & 79 & 81 \\
\hline
\end{tabular}

Bron: ROA

In tabel 2.6 staat de aansluiting naar richting centraal. Het overgrote deel van de alumni heeft een baan gevonden die goed aansluit op de opleiding die zij hebben gevolgd. Ook hier zien we dat oudere alumni vaker binnen de eigen richting werkzaam zijn dan net afgestudeerde UM'ers. Dit kan verschillende oorzaken hebben. Cohorteffecten kunnen een rol spelen. Mogelijk is het karakter van opleidingen of de arbeidsmarkt zodanig veranderd dat het moeilijker of makkelijker wordt om een passende baan te vinden. Daarnaast kan het ook hier enige tijd duren voorat men een passende baan heeft gevonden. Er kan echter ook een beweging in omgekeerde richting plaatsvinden. Naarmate de loopbaan vordert, waaieren alumni mogelijk steeds meer uit over de arbeidsmarkt. Hierbij kan bijvoorbeeld gedacht worden aan allerlei managementachtige functies. In hoofdstuk 4 zal aan dit aspect uitgebreid aandacht worden geschonken.

De verschillen tussen de faculteiten zijn ook hier groot. Medici vinden opnieuw vrijwel allemaal een passende functie. De alumni van meer generieke opleidingen zoals Economie en Cultuur en Wetenschapsstudies komen daarentegen ook in banen terecht die minder goed aansluiten bij de gevolgde opleiding. Zo vindt minder dan de helft van de alumni van de faculteit Cultuur en Wetenschapsstudies een passende baan. Zij komen daarbij in een brede waaier van beroepen terecht. Datzelfde geldt voor de economen, hoewel een aanzienlijk deel in de ICT-sector terechtkomt. 
Tabel 2.6

Werk in eigen of verwante richting in procenten per afstudeercohort, 2002

\begin{tabular}{rccccccc}
\hline & FdCW & FdEWB & FdG & FdGW & FdP & FdR & Totaal \\
\hline $1999-2000$ & 48 & 69 & 100 & 74 & 85 & 81 & 77 \\
$1995-1995$ & 39 & 76 & 96 & 75 & n.v.t. & 73 & 77 \\
$1990-1991$ & n.v.t. & 82 & 96 & 79 & n.v.t. & 81 & 84 \\
\hline
\end{tabular}

Bron: ROA

In tabel 2.7 wordt gepoogd wat meer inzicht te verschaffen in het karakter van de aansluiting tussen beroep en opleiding door beide dimensies simultaan te beschouwen. Met name degenen die zowel onder WO-niveau als buiten de eigen richting werkzaam zijn vormen vanuit arbeidsmarktoogpunt een kwetsbare groep. De tabel laat zien dat ongeveer 10 procent van de alumni tot deze groep behoort. Naarmate de loopbaan vordert, neemt de groep enigszins af in omvang. Na tien jaar heeft 6 procent een baan onder WO-niveau en buiten de eigen richting. Het betreft hierbij vooral gezondheidswetenschappers, juristen en, in iets mindere mate, economen. Zoals gezegd, zal in hoofdstuk 4 dieper op de aansluiting tussen opleiding en beroep worden ingegaan. Daarnaast zal in hoofdstuk 3 aandacht worden geschonken aan een moeizame start. Daarbij zal onder meer worden gekeken naar de vraag of alumni die in het begin van hun loopbaan in een baan onder WO-niveau werkzaam zijn, later in hun loopbaan de (negatieve) gevolgen hiervan ondervinden.

Tabel 2.7

Aansluiting naar opleiding en richting in procenten per afstudeercohort, 2002

\begin{tabular}{lcrr}
\hline & $1999-2000$ & $1995-1996$ & $1990-1991$ \\
\hline Op niveau en in eigen richting & 61 & 61 & 72 \\
Op niveau en buiten eigen richting & 10 & 11 & 9 \\
Onder niveau en in eigen richting & 17 & 17 & 6 \\
Onder niveau en buiten eigen richting & 13 & 12 & 6 \\
\hline
\end{tabular}

Bron: ROA

Leidinggeven is een belangrijk aspect van werk. In het kader van dit hoofdstuk biedt de mate waarin alumni leidinggeven aan collega's een goede indicatie van de groei die tijdens een loopbaan wordt doorgemaakt. Het is niet verrassend dat naarmate de loopbaan vordert leidinggeven een steeds grotere rol gaat spelen. In vergelijking met de UM'ers die pas één jaar geleden zijn afgestudeerd, werken alumni die reeds tien jaar geleden de UM hebben verlaten drie keer zo vaak in een leidinggevende functie. De verschillen tussen de faculteiten zijn - zeker voor het cohort 1990-1991 - relatief gering. Economen zijn na tien jaar het vaakst werkzaam in een leidinggevende functie; medici en gezondheidswetenschappers het minst. Juristen lijken - op basis van deze indicator - de sterkste groei door te maken. Na één jaar blijt het aantal leidinggevende juristen met $13 \%$ nog duidelijk achter bij het gemiddelde van $21 \%$. Na tien jaar zijn juristen echter meer dan gemiddeld in een leidinggevende functie werkzaam. 
Tabel 2.8

Werkzaam in een leidinggevende functie in procenten per afstudeercohort, 2002

\begin{tabular}{lccccccc}
\hline & FdCW & FdEWB & FdG & FdGW & FdP & FdR & Totaal \\
\hline $1999-2000$ & 9 & 20 & 20 & 26 & 27 & 13 & 21 \\
$1995-1995$ & 21 & 49 & 32 & 36 & n.v.t. & 41 & 40 \\
$1990-1991$ & n.v.t. & 71 & 59 & 56 & n.v.t. & 62 & 60 \\
\hline
\end{tabular}

Bron: ROA

De beloning is een erg in het oog springende indicator voor de arbeidsmarktpositie. De beloning geeft een directe indicatie van de waarde van de verworven kwalificaties op de arbeidsmarkt. Na één jaar gaat hier hierbij primair om de in de opleiding verworven kwalificaties. Daarna gaan ook middels ervaring en aanvullende scholing verworven kennis en vaardigheden een steeds grotere rol spelen. In tabel 2.9 wordt een overzicht gegeven van de mediaan van het bruto uurloon. De tabel laat zien dat alumni uit het cohort 1990-1991 per uur bijna twee keer zoveel verdienen als net afgestudeerde UM'ers (respectievelijk $€ 24,45$ en $€ 13,09$ ). De beloning van economen en medici ontloopt elkaar nauwelijks. De mediane beloning voor het cohort 1990-1991 bedraagt respectievelijk $€ 27,72$ en $€ 28,85$ per uur. Het loon van juristen en (ondanks de wat hogere leeftijd) ook gezondheidswetenschappers blijft hierbij wat achter. Ook alumni van de faculteit Cultuur en Wetenschapsstudies en psychologen lijken wat minder goed beloond te worden. Voor deze alumni zijn echter vooralsnog geen cijfers voor reeds tien jaar geleden afgestudeerde UM'ers beschikbaar. Overigens dient opgemerkt te worden dat ongeveer $40 \%$ van de psychologen als AIO werkzaam is, hetgeen uiteraard een negatieve invloed heeft op de hier gepresenteerde beloningscijfers.

Tabel 2.9

Mediaan bruto uurloon in euro's per afstudeercohort, 2002

\begin{tabular}{llllllll}
\hline & FdCW & FdEWB & FdG & FdGW & FdP & FdR & Totaal \\
& & & & & & & \\
$1999-2000$ & 11,38 & 13,35 & 14,92 & 13,61 & 11,78 & 12,02 & 13,09 \\
$1995-1995$ & 15,78 & 20,94 & 19,61 & 18,75 & n.v.t. & 17,97 & 19,64 \\
$1990-1991$ & n.v.t. & 27,72 & 28,85 & 23,16 & n.v.t. & 23,06 & 24,45 \\
\hline
\end{tabular}

Bron: ROA

\subsection{Een evaluatie van de baan en de studiekeuze}

Deze paragraaf heeft een evaluerend karakter. Wat vinden Maastrichtse alumni van hun huidige baan? Zijn ze tevreden? Voldoet de baan aan hun verwachtingen? En, terugkijkend, zouden ze opnieuw voor dezelfde opleiding kiezen? En zouden ze die opleiding opnieuw aan de UM volgen?

Tabel 2.10 biedt inzicht in de werksatisfactie van alumni van de UM. De tabel laat zien dat Maastrichtse alumni over het algemeen tevreden zijn met hun baan. Zo'n 80 
procent geeft aan (zeer) tevreden te zijn. De verschillen tussen de faculteiten en de cohorten zijn over het algemeen gering. Medici zijn het meest tevreden. Bijna 90 procent geeft aan (zeer) tevreden te zijn met de huidige baan. Dit is niet verrassend gezien het specifieke karakter van de opleiding, het duidelijke beroepsbeeld en de goede aansluiting tussen beroep en opleiding.

Tabel 2.10

(Zeer) tevreden met de huidige baan in procenten per afstudeercohort, 2002*

\begin{tabular}{lccccccc}
\hline & FdCW & FdEWB & FdG & FdGW & FdR & Totaal \\
\hline $1995-1995$ & 85 & 76 & 89 & 81 & 75 & 79 \\
$1990-1991$ & n.v.t. & 82 & 89 & 77 & 80 & 81 \\
\hline
\end{tabular}

* Deze vraag is niet gesteld aan alumni uit het cohort 1999-2000

Bron: ROA

Aan de respondenten is ook gevraagd hun huidige werksituatie te confronteren met de verwachtingen die ze hadden bij aanvang van de opleiding aan de UM. In tabel 2.11 worden de resultaten gepresenteerd. Over het algemeen voldoet de huidige werksituatie aan de verwachtingen. Minder dan 10 procent van de alumni geeft aan dat de huidige situatie (veel) slechter is dan verwacht. Dit is niet verrassend gezien de hoge werksatisfactie, zoals uit tabel 2.10 bleek. Opvallend is dat de medici uit het cohort 1995-1996 er in negatieve zin wat lijken uit te springen. Het betreft hierbij vooral huisartsen en sociaal geneeskundigen. Voor alumni van de faculteit Cultuur en Wetenschapsstudies voldoet de huidige situatie volledig aan de verwachtingen.

Tabel 2.11

Werksituatie (veel) slechter dan verwacht in procenten per afstudeercohort, 2002

\begin{tabular}{cccccccc}
\hline & FdCW & FdEWB & FdG & FdGW & FdR & Totaal \\
\hline $1995-1995$ & 0 & 3 & 9 & 6 & 6 & 5 \\
$1990-1991$ & n.v.t. & 6 & 4 & 2 & 2 & 3 \\
\hline
\end{tabular}

${ }^{*}$ Deze vraag is niet gesteld aan alumni uit het cohort 1999-2000

Bron: ROA

De studiekeuze heeft een belangrijke invloed op de latere levensloop en de beroepsloopbaan. Spijt achteraf over de studiekeuze is daarom ook een belangrijke indicator voor de tevredenheid met de huidige situatie. Werkenden geven hiermee aan dat ze wellicht een andere werkplek voor ogen hebben gehad toen zij aan de studie begonnen. Dat kan een werkplek zijn die inhoudelijk beter past of die hen in staat zou hebben gesteld andere levensdoelen te realiseren. De niet-werkende UM'er zou wellicht met een andere studie wel passend werk hebben kunnen vinden.

De tabellen 2.12a tot en met 2.12c laten zien hoe alumni van de UM op hun studiekeuze terugkijken. Zo'n driekwart van de dit jaar benaderde alumni geeft aan dat ze opnieuw voor dezelfde studie aan de UM gekozen zouden hebben. Dit 
percentage is het hoogst voor de economen en de medici. Voor alle cohorten geldt dat meer dan 80 procent van de medici en economen opnieuw voor dezelfde studie aan de UM zouden kiezen. Over het algemeen zouden weinig Maastrichtse alumni dezelfde opleiding aan een andere universiteit hebben willen volgen. Dat geldt vooral voor de UM'ers die vijf en tien jaar geleden afgestudeerd zijn.

Minder dan 20\% zou voor een andere WO-opleiding gekozen hebben. Vooral gezondheidswetenschappers geven aan spijt te hebben van hun keuze. Geneeskunde en psychologie zijn veel genoemde alternatieven. Mogelijk betreft het hierbij studenten die als gevolg van de numerus fixus bij geneeskunde buiten de boot zijn gevallen. Een gering aantal Maastrichtse alumni geeft aan liever een opleiding op een lager niveau gevolgd te hebben.

Tabel $2.12 a$

De studiekeuze achteraf één jaar na afstuderen in procenten cohort 1999-2000, 2002 (Zou u de opleiding opnieuw kiezen?)

\begin{tabular}{lrrrrrrr}
\hline & FdCW & FdEWB & FdG & FdGW & FdP & FdR & Totaal \\
\hline Ja, en opnieuw aan UM & 63 & 80 & 83 & 63 & 85 & 78 & 73 \\
Ja, aan andere universiteit & 4 & 4 & 9 & 4 & 12 & 9 & 6 \\
Nee, een andere WO-opleiding & 33 & 15 & 3 & 30 & 3 & 10 & 18 \\
Nee, een opl. op lager niveau & 0 & 2 & 5 & 3 & 0 & 3 & 3 \\
& & & & & & &
\end{tabular}

Bron: ROA

Tabel $2.12 b$

De studiekeuze achteraf vijf jaar na afstuderen in procenten cohort 1995-1996, 2002 (Zou u de opleiding opnieuw kiezen?)

\begin{tabular}{lrrrrrr}
\hline & FdCW & FdEWB & FdG & FdGW & FdR & Totaal \\
& & & & & & \\
Ja, en opnieuw aan UM & 71 & 82 & 86 & 70 & 78 & 77 \\
Ja, aan andere universiteit & 6 & 3 & 4 & 2 & 5 & 3 \\
Nee, een andere WO-opleiding & 12 & 13 & 3 & 26 & 13 & 16 \\
Nee, een opl. op lager niveau & 12 & 3 & 7 & 2 & 4 & 4
\end{tabular}

\section{Bron: ROA}

Tabel $2.12 c$

De studiekeuze achteraf tien jaar na afstuderen in procenten cohort 1990-1991, 2002 (Zou u de opleiding opnieuw kiezen?)

\begin{tabular}{lrrrrr}
\hline & FdEWB & FdG & FdGW & FdR & Totaal \\
\hline Ja, en opnieuw aan UM & 82 & 88 & 73 & 80 & 79 \\
Ja, aan andere universiteit & 3 & 2 & 1 & 4 & 2 \\
Nee, een andere WO-opleiding & 12 & 10 & 23 & 11 & 16 \\
Nee, een opl. op lager niveau & 3 & 0 & 3 & 4 & 3 \\
Bron: ROA & & & & &
\end{tabular}

Bron: ROA 


\subsection{Conclusie}

Het gaat de alumni van de Universiteit Maastricht momenteel voor de wind. De werkloosheid is laag. Alleen onder recent afgestudeerde alumni is er sprake van werkloosheid van enige betekenis, met name onder juristen (4 procent). De wat oudere alumnus verdwijnt wel steeds vaker uit het (betaalde) arbeidsproces. Van de groep die tien jaar geleden afstudeerde heeft 86 procent een betaalde baan, is 1 procent werkloos en doet 12 procent iets anders. Vooral juristen en gezondheidswetenschappers kiezen voor een andere invulling. Ook beginnen steeds meer UM'ers een eigen bedrijf. Tien jaar na afstuderen verdient zo'n 10 procent als zelfstandige zijn brood. Het zijn vooral medici en juristen die hiervoor kiezen.

Zoals gezegd, het gaat de UM'er voor de wind. Na een aantal jaren weet zo'n 80 procent een vaste aanstelling te verwerven. Met name economen verwerven relatief snel een vaste baan. Na één jaar heeft driekwart van de economen een contract voor onbepaalde tijd verworven. Over het algemeen werken UM'ers in een functie waarvoor de werkgever een WO-opleiding vereist. Ongeveer driekwart van de alumni heeft een baan op WO-niveau. Voor de net afgestudeerden is dit percentage iets lager (70); voor de alumni uit het cohort 1990-1991 iets hoger (80). Dit verschil is niet verwonderlijk, aangezien alumni mogelijk aanvankelijk geen passende baan weten te verwerven, maar hier later in de loopbaan wel in slagen. De verschillen tussen de faculteiten zijn aanzienlijk. Vrijwel alle medici hebben een baan op WO-niveau verworven. Economen komen daarentegen relatief vaak in banen terecht waarvoor de werkgever niet expliciet een WO-diploma vereist. Vooral voor adviseursfuncties nemen werkgevers ook met een HBO-diploma genoegen. Ook gezondheidswetenschappers werken vaak op HBO-niveau of lager. Het feit dat gezondheidswetenschappers vaak reeds ervaring hebben opgedaan in bijvoorbeeld de verpleging en ook vaak na het afronden van de academische studie in hun vakgebied werkzaam blijven, speelt hierbij echter een belangrijke rol. Het overgrote deel van de alumni (meer dan 75 procent) heeft een baan gevonden die goed aansluit op de opleidingsrichting die zij hebben gevolgd. Ook hier zien we dat oudere alumni vaker binnen de eigen richting werkzaam zijn dan net afgestudeerde UM'ers. De verschillen tussen de faculteiten zijn ook hier groot. Medici vinden opnieuw vrijwel allemaal een passende functie. De alumni van meer generieke opleidingen zoals Economie en Cultuur en Wetenschapsstudies komen daarentegen ook in banen terecht die minder goed aansluiten bij de gevolgde opleiding.

De mate waarin alumni leidinggeven aan collega's geeft een goede indicatie van de groei die tijdens een loopbaan wordt doorgemaakt. Het is niet verrassend dat naarmate de loopbaan vordert leidinggeven een steeds grotere rol gaat spelen. Van de UM'ers die pas één jaar geleden zijn afgestudeerd, werkt zo'n 20 procent in een leidinggevende functie. Voor alumni die reeds tien jaar geleden de UM hebben verlaten is dit percentage drie keer zo hoog. De verschillen tussen de faculteiten zijn relatief gering. Economen zijn na tien jaar het vaakst werkzaam in een leidinggevende functie; medici en gezondheidswetenschappers het minst. Een tweede en erg in het oog springende indicator voor de groei is de beloning. Alumni uit het cohort 1990-1991 verdienen per uur bijna twee keer zoveel als net afgestudeerde UM'ers 
(respectievelijk $€ 24,45$ en $€ 13,09$ ). De beloning van economen en medici ontloopt elkaar nauwelijks. Het loon van juristen en (ondanks de wat hogere leeftijd) ook gezondheidswetenschappers blijft hierbij wat achter.

Dat het de UM'ers voor de wind gaat, komt ook tot uiting in de werksatisfactie. Zo'n 80 procent van de Maastrichtse alumni geeft aan (zeer) tevreden te zijn met de huidige baan. De verschillen tussen de faculteiten en de cohorten zijn over het algemeen gering. Medici zijn het meest tevreden. Bijna 90 procent geeft aan (zeer) tevreden te zijn met de huidige baan. Dit is niet verrassend gezien het specifieke karakter van de opleiding, het duidelijke beroepsbeeld en de goede aansluiting tussen beroep en opleiding. Bovendien voldoet de huidige werksituatie aan de verwachtingen aan het begin van de studie. Minder dan 10 procent van de alumni geeft aan dat de huidige situatie (veel) slechter is dan verwacht.

Zo'n driekwart van de dit jaar benaderde alumni geeft, achteraf terugkijkend, aan dat ze opnieuw voor dezelfde studie aan de UM gekozen zouden hebben. Dit percentage is het hoogst voor de economen en de medici. Voor alle cohorten geldt dat meer dan 80 procent van de medici en economen opnieuw voor dezelfde studie aan de UM zouden kiezen. Over het algemeen zouden weinig Maastrichtse alumni dezelfde opleiding aan een andere universiteit hebben willen volgen. Met name alumni die vijf en tien jaar geleden afgestudeerd zijn zouden opnieuw voor de UM kiezen. Minder dan $20 \%$ zou voor een andere WO-opleiding gekozen hebben. Vooral gezondheidswetenschappers geven aan spijt te hebben van hun keuze. Geneeskunde en psychologie zijn veel genoemde alternatieven. 



\section{De loopbaan}

In hoofdstuk 2 stond de huidige arbeidsmarktpositie van Maastrichtse alumni centraal. Hierbij werd gekeken naar de verschillende cohorten in de verschillende fasen van hun loopbaan. In dit hoofdstuk wordt voor een andere insteek gekozen. Via een longitudinale aanpak wordt de loopbaan van de Maastrichtse alumni gereconstrueerd. Van het cohort 1990-1991 zijn inmiddels drie metingen beschikbaar: een meting zo'n anderhalf jaar na afstuderen in het najaar van 1992, een meting vijf jaar na afstuderen in het voorjaar van 1997 en een meting tien jaar na het verlaten van de opleiding in het voorjaar van 2002. Het cohort 1995-1996 is inmiddels twee keer benaderd: in 1997 en in 2002. Door de alumni vaker te benaderen wordt het mogelijk de dynamiek in de loopbanen van de Maastrichtse alumni in kaart te brengen en kunnen de verschillende fasen in de loopbaan in hun onderlinge samenhang worden geanalyseerd.

De opzet van dit hoofdstuk is als volgt. In de vragenlijst wordt aan alumni gevraagd hun loopbaan middels een zogenaamde kalender te reconstrueren. Op deze wijze worden de verschillende banen, maar ook de periodes van inactiviteit, retrospectief in kaart gebracht. Paragraaf 2 vat deze retrospectieve resultaten samen. Verschillende indicatoren, zoals het aantal banen, het aantal periodes van werkloosheid en het aantal onvrijwillige ontslagen, worden onder de loep genomen. Met behulp van deze indicatoren kan een eerste schets van de loopbaanpatronen worden gegeven. In paragraaf 3 wordt de arbeidsmarktpositie van de Maastrichtse alumni middels een longitudinale aanpak geanalyseerd. Door te kijken naar indicatoren als beloning, baanzekerheid en onderbenutting kunnen de verschillende fasen in de loopbaan met elkaar in verband worden gebracht. In paragraaf 4 wordt nog een stapje verder gegaan. Met behulp van een verklarende analyse wordt gepoogd de onderliggende factoren van het loopbaansucces bloot te leggen. Hierbij kan, naast het loopbaanverloop waarop in paragraaf 3 de aandacht wordt gevestigd, gedacht worden aan persoonskenmerken, de schoolloopbaan, het type werkgever, de samenstelling van het huishouden, e.d.

\subsection{Een retrospectieve kijk op loopbanen}

Een belangrijk kenmerk van een loopbaan wordt gevormd door het aantal banen dat de alumnus gedurende zijn loopbaan tot nu toe heeft gehad. Is er sprake van een stabiele loopbaan met een beperkt aantal baanwisselingen? Of heeft de loopbaan een wat turbulenter karakter en wisselt de Maastrichtse alumnus vaak van baan? Uit tabel 3.1 blijkt dat de UM'ers die vijf jaar geleden zijn afgestudeerd gemiddeld bijna 3 banen hebben gehad. Voor de UM'ers die de universiteit tien jaar geleden hebben verlaten, ligt dit aantal met 3,3 maar weinig hoger. Dit geringe verschil kan twee oorzaken hebben. Enerzijds komen loopbanen na een aantal jaren in een rustiger vaarwater. Mensen vinden na verloop van tijd een baan die goed aanluit bij hun wensen en capaciteiten, de baanzekerheid wordt groter en ook andere factoren (bijvoorbeeld de baan van een eventuele partner) werken mobiliteitsverlagend. Anderzijds kunnen cohorteffecten een rol spelen. Zo kan de arbeidsmarktsituatie 
invloed hebben op de mobiliteit. De gedwongen mobiliteit zal geringer zijn, wanneer de arbeidsmarkt gekenmerkt wordt door een grote krapte. Een tekort aan personeel kan daarentegen een positief effect hebben op de vrijwillige mobiliteit, omdat er meer mogelijkheden zijn om de positie te verbeteren.

De verschillen tussen de faculteiten zijn opmerkelijk gering. Juristen lijken het minst mobiel, terwijl medici en alumni van de faculteit Cultuur en Wetenschapsstudies het vaakst van baan verwisselen. In hoofdstuk 2 hebben we gezien dat juist deze twee groepen het meeste moeite hebben een vaste baan te verwerven. Overigens geeft deze tabel een heel aardig beeld van de individuele loopbaanpatronen. De meeste alumni hebben 2, 3 of 4 banen gehad. Zeer stabiele loopbanen (slechts één baan) of turbulente loopbanen ( 5 of meer banen) zijn relatief schaars. Zo heeft van de alumni die tien jaar geleden zijn afgestudeerd slechts 8 procent maar één baan gehad, terwijl ruim 20 procent vijf of meer banen heeft gehad.

Tabel 3.1

Gemiddeld aantal banen per afstudeercohort, 2002

\begin{tabular}{ccccccc}
\hline & FdCW & FdEWB & FdG & FdGW & FdR & Totaal \\
\hline $1995-1996$ & 3,4 & 2,9 & 3,4 & 2,7 & 2,5 & 2,8 \\
$1990-1991$ & n.v.t. & 3,2 & 4,2 & 3,2 & 2,7 & 3,3 \\
\hline
\end{tabular}

Bron: ROA

Het aantal werkgevers behoeft niet in de pas te lopen met het aantal banen. Zo kan iemand binnen het bedrijf van baan wisselen. Aan de andere kant kan in het geval van detacheringcontracten of in het geval van een opleidingsplaats het aantal werkgevers het aantal banen overtreffen. Dit laatste effect zien we terug bij de medici, zoals tabel 3.2 laat zien. Voor de alumni van de andere faculteiten blijkt het aantal banen iets groter te zijn dan het aantal werkgevers. Met name bij juristen is het verschil te verwaarlozen. Dit betekent dat juristen relatief zelden bij een bepaalde werkgever van baan wisselen. Bij alumni van de faculteit Cultuur en Wetenschapsstudies is het verschil het grootst. Zij hebben gemiddeld 2,4 werkgevers gehad gedurende de eerste vijf jaar van hun loopbaan, terwijl het gemiddeld aantal banen 3,4 bedraagt. Alumni van deze faculteit wisselen dus blijkbaar relatief vaak bij dezelfde werkgever van baan.

Tabel 3.2

Gemiddeld aantal werkgevers per afstudeercohort, 2002

\begin{tabular}{lcccccc}
\hline & FdCW & FdEWB & FdG & FdGW & FdR & Totaal \\
& & & & & & \\
\hline $1995-1996$ & 2,4 & 2,3 & 3,7 & 2,5 & 2,5 & 2,6 \\
$1990-1991$ & n.v.t. & 2,7 & 5,5 & 3,0 & 2,7 & 3,4 \\
& & & & & & \\
\hline
\end{tabular}

Bron: ROA 
Tabel 3.3 laat zien hoe vaak UM'ers werkloos zijn geweest. Vaak zal er hierbij sprake zijn van intredewerkloosheid: een periode van werkloosheid meteen na het afstuderen. Uit de tabel blijkt dat gemiddeld slechts de helft van de Maastrichtse alumni een periode van werkloosheid meemaakt. De verschillen tussen de faculteiten zijn te verwaarlozen. Dit gunstige beeld wordt ook weerspiegeld door het feit dat slechts ruim 6 procent van de Maastrichtse alumni vaker dan één keer werkloos is (geweest) gedurende zijn of haar loopbaan.

Tabel 3.3

Gemiddeld aantal keren werkloos per afstudeercohort, 2002

\begin{tabular}{ccccccc}
\hline & FdCW & FdEWB & FdG & FdGW & FdR & Totaal \\
\hline $1995-1996$ & 0,6 & 0,4 & 0,6 & 0,5 & 0,5 & 0,5 \\
$1990-1991$ & n.v.t. & 0,3 & 0,5 & 0,5 & 0,3 & 0,4
\end{tabular}

Bron: ROA

Mobiliteit kan, zoals eerder opgemerkt, een vrijwillig of onvrijwillig karakter hebben. De belangrijkste oorzaak voor onvrijwillige mobiliteit is het aflopen van tijdelijke contracten. Uit tabel 3.4 blijkt dat gemiddeld slechts de helft van de Maastrichtse alumni een keer onvrijwillig ontslagen is. De verschillen tussen de faculteiten zijn opnieuw te verwaarlozen. Deze cijfers komen aardig overeen met het beeld zoals geschetst in tabel 3.3. Vaak zal een periode van werkloosheid immers worden voorafgegaan door onvrijwillig ontslag. Het is dan ook niet verrassend dat slechts zo'n 10 procent van de Maastrichtse alumni vaker dan één keer onvrijwillig een baan heeft moeten verlaten. Geconcludeerd kan worden dat het overgrote deel van de mobiliteit van Maastrichtse alumni een vrijwillig karakter heeft.

Tabel 3.4

Gemiddeld aantal keren onvrijwillig ontslag per afstudeercohort, 2002

\begin{tabular}{lcccccc}
\hline & FdCW & FdEWB & FdG & FdGW & FdR & Totaal \\
\hline 1995-1996 & 0,5 & 0,4 & 0,5 & 0,3 & 0,2 & 0,4 \\
$1990-1991$ & n.v.t. & 0,5 & 0,5 & 0,6 & 0,3 & 0,5 \\
& & & & & & \\
\hline
\end{tabular}

Bron: ROA

In tabel 3.5 wordt gepoogd inzicht te verschaffen in de kwaliteit van het werk van Maastrichtse alumni. Onderbenutting is hiervoor een belangrijke indicator. Wanneer een academicus beneden zijn of haar niveau werkzaam is, heeft dit in veel gevallen gevolgen voor de beloning, maar ook voor bijvoorbeeld de loopbaanmogelijkheden. Ook blijken alumni die beneden hun niveau werkzaam zijn, vaak minder tevreden te zijn met hun werk. Uit de tabel blijkt dat Maastrichtse alumni gemiddeld minder dan één keer werkzaam zijn (geweest) in een baan beneden hun niveau. Gegeven het feit dat UM'ers gemiddeld ongeveer 3 banen hebben gehad tijdens hun loopbaan, betekent dit dat er in ongeveer 30 procent van de banen sprake is van onderbenutting. Medici zijn vrijwel altijd op WO-niveau werkzaam. Dit hebben we ook al in 
hoofdstuk 2 gezien. Economen, gezondheidswetenschappers en vooral alumni van de faculteit Cultuur en Wetenschapsstudies hebben gemiddeld (meer dan) één keer een baan onder WO-niveau. Benadrukt moet worden dat het hier om gemiddelden gaat. Het kan dus heel goed betekenen dat het onderbenuttingsprobleem zich concentreert bij een specifieke (kleine) groep. In de volgende paragraaf zal hier dieper op worden ingegaan.

Tabel 3.5

Gemiddeld aantal banen waarin er sprake was van onderbenutting per afstudeercohort, 2002

\begin{tabular}{lcccccc}
\hline & FdCW & FdEWB & FdG & FdGW & FdR & Totaal \\
\hline $1995-1996$ & 1,3 & 1,1 & 0,0 & 1,1 & 0,6 & 0,9 \\
$1990-1991$ & n.v.t. & 0,9 & 0,0 & 1,0 & 0,9 & 0,8
\end{tabular}

Bron: ROA

In het voorafgaande is gekeken naar verschillen in loopbaanpatronen tussen alumni van de verschillende faculteiten. In de tabellen 3.6a en 3.6b wordt voor een andere invalshoek gekozen: de verschillen tussen mannen en vrouwen. De tabellen laten zien dat de loopbanen van mannen en vrouwen, op basis van de hier gepresenteerde indicatoren, opmerkelijk weinig verschillen vertonen. In de volgende paragraaf zullen we laten zien dat verschillen in de loopbaan tussen mannen en vrouwen op andere manieren, zoals het aantal arbeidsuren en de beloning, tot uiting komen.

Tabel 3.6a

Verschillen in loopbaanpatroon tussen mannen en vrouwen, cohort 1995-1996, 2002

\begin{tabular}{lccc}
\hline & Mannen & Vrouwen & Totaal \\
\hline Aantal banen & 2,7 & 2,9 & 2,8 \\
Aantal werkgevers & 2,4 & 2,7 & 2,6 \\
Aantal keren werkloos & 0,5 & 0,5 & 0,5 \\
Aantal keren onvrijwillig ontslag & 0,4 & 0,3 & 0,4 \\
Aantal banen met onderbenutting & 0,7 & 0,9 & 0,9 \\
\end{tabular}

Bron: ROA

Tabel 3.6b

Verschillen in loopbaanpatroon tussen mannen en vrouwen, cohort 1990-1991, 2002

\begin{tabular}{lccc}
\hline & Mannen & Vrouwen & Totaal \\
\hline Aantal banen & 3,5 & 3,2 & 3,3 \\
Aantal werkgevers & 3,2 & 3,6 & 3,4 \\
Aantal keren werkloos & 0,4 & 0,5 & 0,4 \\
Aantal keren onvrijwillig ontslag & 0,5 & 0,5 & 0,5 \\
Aantal banen met onderbenutting & 0,9 & 0,7 & 0,8 \\
\hline
\end{tabular}

Bron: ROA 


\subsection{Individuele loopbaanpatronen}

In deze paragraaf worden de verschillende fasen in de loopbaan met behulp van longitudinale analyses in kaart gebracht. De nadruk ligt hierbij op de impact van de start van de loopbaan op de rest van de carrière. In de tabellen $3.7 \mathrm{a}$ en $3.7 \mathrm{~b}$ wordt gekeken naar de baanzekerheid. Blijft de arbeidsmarktpositie van alumni, die in het begin van hun loopbaan werkzaam zijn in een tijdelijke baan, ook in latere fasen kwetsbaar? Of heeft het hebben van een tijdelijke baan aan het begin van de loopbaan nauwelijks invloed op de baanzekerheid in een latere fase? Tabel 3.7a laat zien dat voor alumni uit het cohort 1995-1996 de start in een tijdelijke baan ook na vijf jaar nog merkbaar is. Van degenen die na één jaar een vaste baan hadden verworven, werkt na vijf jaar slechts 7 procent met een tijdelijk contract. Voor degenen die na één jaar een tijdelijke aanstelling hadden, is dit meer dan 20 procent.

Tabel 3.7a

Aard dienstverband naar fase in de loopbaan in procenten, cohort 1995-1996

\begin{tabular}{lcc}
\hline & \multicolumn{2}{c}{ Na één jaar } \\
& Vaste aanstelling & Tijdelijke aanstelling \\
& & \\
Na vijf jaar & 93 & 21 \\
Vaste aanstelling & 7 & 100 \\
Tijdelijke aanstelling & 100 & \\
Totaal & & \\
\hline Bron: ROA & & \\
\hline
\end{tabular}

Bron: ROA

Tabel 3.7b laat voor het cohort 1990-1991 een vergelijkbaar beeld zien. Na vijf jaar heeft slechts 59 procent van de alumni die na één jaar een tijdelijk contract hadden, een vaste baan verworven. Uit de tabel blijkt echter ook dat na tien jaar het effect van het al dan niet hebben van een vaste aanstelling na één jaar volledig is verdwenen. Meer dan 80 procent van de alumni heeft een vaste baan, ongeacht de baanzekerheid in de loopbaan tot dan toe.

Tabel 3.7b

Aard dienstverband naar fase in de loopbaan in procenten, cohort 1990-1991

\begin{tabular}{lcr} 
& \multicolumn{2}{c}{ Na één jaar } \\
& Vaste aanstelling & Tijdelijke aanstelling \\
& & \\
Na vijf jaar & 90 & 59 \\
Vaste aanstelling & 10 & 100 \\
Tijdelijke aanstelling & 100 & \\
Totaal & & 84 \\
Na tien jaar & 83 & 17 \\
Vaste aanstelling & 17 & 100 \\
Tijdelijke aanstelling & 100 & \\
Totaal & & \\
& & \\
Bron: & & \\
& &
\end{tabular}

Bron: ROA 
De vraag rijst in hoeverre het in de tabellen 3.7a en 3.7b geschetste beeld het gevolg is van institutionele factoren. Zo kiezen medici vaak voor een (per definitie tijdelijke) opleidingsplaats na afstuderen. Om hier zicht op te krijgen, worden in tabel 3.8 de in tabel 3.7a gepresenteerde cijfers uitgesplitst naar faculteit. Tabel 3.8 laat inderdaad zien dat de medici voor een belangrijk deel verantwoordelijk zijn voor het effect van een geringe baanzekerheid na één jaar op het al dan niet hebben van een vast contract na vijf jaar. Bij de juristen, economen en gezondheidswetenschappers is het effect weliswaar aanwezig, maar veel kleiner. Geconcludeerd kan worden dat over het algemeen slechts een kleine groep de gevolgen van een geringe baanzekerheid aan het begin van de loopbaan na vijf jaar nog steeds ondervindt. Bovendien is dit effect na tien jaar volledig verdwenen.

Tabel 3.8

Aard dienstverband naar fase in de loopbaan en faculteit in procenten, cohort 1995-1996

\begin{tabular}{|c|c|c|c|}
\hline & & \multicolumn{2}{|c|}{ Na één jaar } \\
\hline & & Vaste aanstelling & Tijdelijke aanstelling \\
\hline & Na vijf jaar & & \\
\hline \multirow[t]{3}{*}{ FdCW } & Vaste aanstelling & 100 & 25 \\
\hline & Tijdelijke aanstelling & 0 & 75 \\
\hline & Totaal & 100 & 100 \\
\hline \multirow[t]{3}{*}{ FdEWB } & Vaste aanstelling & 97 & 89 \\
\hline & Tijdelijke aanstelling & 3 & 11 \\
\hline & Totaal & 100 & 100 \\
\hline \multirow[t]{3}{*}{ FdG } & Vaste aanstelling & 75 & 43 \\
\hline & Tijdelijke aanstelling & 25 & 57 \\
\hline & Totaal & 100 & 100 \\
\hline \multirow[t]{3}{*}{ FdGW } & Vaste aanstelling & 88 & 86 \\
\hline & Tijdelijke aanstelling & 13 & 14 \\
\hline & Totaal & 100 & 100 \\
\hline \multirow[t]{3}{*}{ FdR } & Vaste aanstelling & 96 & 89 \\
\hline & Tijdelijke aanstelling & 5 & 12 \\
\hline & Totaal & 100 & 100 \\
\hline
\end{tabular}

Bron: ROA

In de tabellen 3.9a en 3.9b wordt gekeken naar het aantal arbeidsuren. De tabellen laten zien dat het werken in deeltijd (dat wil zeggen: 32 uur per week of minder) een 'hardnekkig' fenomeen is. Voor het cohort 1995-1996 geldt dat bijna de helft van degenen die na één jaar parttime werkten, dat na vijf jaar nog steeds doet. Van de groep die na één jaar een volledige aanstelling had, werkt slechts 21 procent in deeltijd. Tabel 3.9b laat voor het cohort 1990-1991 zien dat ook na tien jaar weinig is veranderd. Bijna de helft (47 procent) van de alumni die na één jaar in deeltijd werkten, doet dat na tien jaar ook. Deze groep wordt zelfs in de loop der jaren weer groter. Na vijf jaar blijkt namelijk tweederde van de parttime starters fulltime te werken. Zo'n 15 procent van de parttime starters komt dus tussen de vijf en tien jaar na afstuderen opnieuw in een parttime baan terecht. 
Tabel 3.9a

Arbeidsuren naar fase in de loopbaan in procenten, cohort 1995-1996

\begin{tabular}{|c|c|c|}
\hline & \multicolumn{2}{|c|}{ Na één jaar } \\
\hline & Fulltime & Parttime \\
\hline \multicolumn{3}{|c|}{ Na vijf jaar } \\
\hline Fulltime & 80 & 51 \\
\hline Parttime & 21 & 49 \\
\hline Totaal & 100 & 100 \\
\hline \multicolumn{3}{|c|}{ Bron: ROA } \\
\hline \multicolumn{3}{|c|}{ Tabel $3.9 b$} \\
\hline \multicolumn{3}{|c|}{ Arbeidsuren naar fase in de loopbaan in procenten, cohort 1990-1991 } \\
\hline & \multicolumn{2}{|c|}{ Na één jaar } \\
\hline & Fulltime & Parttime \\
\hline \multicolumn{3}{|c|}{ Na vijf jaar } \\
\hline Fulltime & 82 & 67 \\
\hline Parttime & 17 & 33 \\
\hline Totaal & 100 & 100 \\
\hline \multicolumn{3}{|c|}{$\mathrm{Na}$ tien jaar } \\
\hline Fulltime & 71 & 53 \\
\hline Parttime & 29 & 47 \\
\hline Totaal & 100 & 100 \\
\hline
\end{tabular}

Bron: ROA

De verklaring voor dit patroon ligt voor de hand. Persoonlijke omstandigheden, zoals het hebben van zorgtaken, doen mensen vaak kiezen voor een parttime baan. Tabel 3.10 illustreert dit. In deze tabel worden de in tabel $3.9 \mathrm{~b}$ gepresenteerde cijfers uitgesplitst naar geslacht. Deze uitsplitsing ligt voor de hand, aangezien het een bekend gegeven is dat vooral vrouwen in deeltijd werken. De tabel laat zien dat zo'n 90 procent van de mannen die na één jaar fulltime werkzaam zijn, na tien jaar nog steeds een volledige werkweek hebben. Voor vrouwen ziet dit beeld er volledig anders uit. Na tien jaar heeft nog slechts 56 procent van de vrouwen die na één jaar fulltime werkten, nog een werkweek van meer dan 32 uur.

Van de mannen die na één jaar parttime werkten, komt het overgrote deel later in een fulltime baan terecht. Na vijf jaar geldt dit voor maar liefst 83 procent van de parttime starters; na tien jaar is dit aantal met 67 procent wat lager. Ook hier ziet het beeld er voor vrouwen anders uit. Na vijf jaar werkt 44 procent van de parttime starters nog steeds in deeltijd. Na tien jaar is dit percentage zelfs weer gestegen tot 56 procent. Er kan worden geconcludeerd dat ten aanzien van het aantal arbeidsuren de loopbaanpatronen van mannen en vrouwen aanzienlijke verschillen vertonen. Daar waar mannen, ook wanneer ze in een parttime baan gestart zijn, na vijf en tien jaar meest een volledige werkweek hebben, kiezen vrouwen veel vaker voor een parttime aanstelling. Na tien jaar is het verschil tussen vrouwelijke parttime 
en fulltime starters relatief klein geworden. Dit wijst erop dat vrouwen - vooral vanwege de zorg voor kinderen - vrijwillig kiezen voor een parttime baan.

Tabel 3.10

Arbeidsuren naar fase in de loopbaan en geslacht in procenten, cohort 1990-1991

\begin{tabular}{|c|c|c|c|}
\hline & & \multicolumn{2}{|c|}{$\mathrm{Na}$ één jaar } \\
\hline & & Fulltime & Parttime \\
\hline & Na vijf jaar & & \\
\hline \multirow[t]{3}{*}{ Mannen } & Fulltime & 94 & 83 \\
\hline & Parttime & 6 & 17 \\
\hline & Totaal & 100 & 100 \\
\hline \multirow[t]{4}{*}{ Vrouwen } & Fulltime & 73 & 56 \\
\hline & Parttime & 27 & 44 \\
\hline & Totaal & 100 & 100 \\
\hline & Na tien jaar & & \\
\hline \multirow[t]{3}{*}{ Mannen } & Fulltime & 90 & 67 \\
\hline & Parttime & 11 & 33 \\
\hline & Totaal & 100 & 100 \\
\hline \multirow[t]{3}{*}{ Vrouwen } & Fulltime & 56 & 44 \\
\hline & Parttime & 44 & 56 \\
\hline & Totaal & 100 & 100 \\
\hline
\end{tabular}

Bron: ROA

In de tabellen 3.11a en 3.11b staat de aansluiting tussen de verworven kennis en vaardigheden en de baan centraal. Tabel 3.11a heeft betrekking op het cohort 19951996. Uit de tabel blijkt dat een moeizame start na vijf jaar nog steeds een negatief effect heeft. Ruim de helft (52 procent) van de alumni die beneden WO-niveau startten, werkt na vijf jaar nog steeds beneden zijn of haar niveau. Opvallend is dat bijna 15 procent van degenen die op WO-niveau zijn gestart na vijf jaar een stapje terug heeft gedaan. Tabel 3.11b laat zien dat voor het cohort 1990-1991 onderbenutting ook na tien jaar een hardnekkig fenomeen blijkt te zijn. Alumni die na één jaar beneden WO-niveau werkzaam waren, zijn na tien jaar nog steeds relatief vaak onder hun niveau werkzaam (45 procent).

Tabel 3.11a

Aansluiting naar niveau naar fase in de loopbaan in procenten, cohort 1995-1996

\begin{tabular}{lcc}
\hline & WO-niveau & Na één jaar \\
& & \\
& & \\
\hline Na vijf jaar & & 48 \\
WO-niveau & 86 & 52 \\
Onder WO-niveau & 14 & 100 \\
Totaal & 100 & \\
\hline
\end{tabular}

Bron: ROA 
Tabel $3.11 b$

Aansluiting naar niveau naar fase in de loopbaan in procenten, cohort 1990-1991

\begin{tabular}{lcc}
\hline & \multicolumn{2}{c}{ Na één jaar } \\
& WO-niveau & Onder WO-niveau \\
& & \\
Na vijf jaar & 72 & 32 \\
WO-niveau & 27 & 68 \\
Onder WO-niveau & 100 & 100 \\
Totaal & & \\
Na tien jaar & 90 & 55 \\
WO-niveau & 10 & 45 \\
Onder WO-niveau & 100 & 100 \\
Totaal & & \\
& & \\
\hline Bron: ROA & & \\
\end{tabular}

Bron: ROA

Tabel 3.12

Aansluiting naar niveau naar fase in de loopbaan en faculteit in procenten, cohort 1995-1996

\begin{tabular}{|c|c|c|c|}
\hline & & \multicolumn{2}{|c|}{ Na één jaar } \\
\hline & & WO-niveau & Onder WO-niveau \\
\hline & Na vijf jaar & & \\
\hline \multirow[t]{3}{*}{ FdCW } & WO-niveau & 60 & 100 \\
\hline & Onder WO-niveau & 40 & 0 \\
\hline & Totaal & 100 & 100 \\
\hline \multirow[t]{3}{*}{ FdEWB } & WO-niveau & 83 & 42 \\
\hline & Onder WO-niveau & 18 & 58 \\
\hline & Totaal & 100 & 100 \\
\hline \multirow[t]{3}{*}{ FdG } & WO-niveau & 100 & - \\
\hline & Onder WO-niveau & 0 & - \\
\hline & Totaal & 100 & - \\
\hline \multirow[t]{3}{*}{ FdGW } & WO-niveau & 80 & 46 \\
\hline & Onder WO-niveau & 20 & 54 \\
\hline & Totaal & 100 & 100 \\
\hline \multirow[t]{3}{*}{ FdR } & WO-niveau & 92 & 71 \\
\hline & Onder WO-niveau & 8 & 29 \\
\hline & Totaal & 100 & 100 \\
\hline
\end{tabular}

Bron: ROA

Om meer zicht te krijgen op het fenomeen onderbenutting, worden in tabel 3.12 de cijfers uit tabel 3.11a uitgesplitst naar faculteit. Uit de tabel blijkt dat vooral economen en gezondheidswetenschappers verantwoordelijk zijn voor het feit dat een start onder WO-niveau voor Maastrichtse alumni relatief vaak leidt tot een verdere loopbaan in banen onder WO-niveau. Maar liefst 58 procent van de onder hun niveau startende economen werkt na vijf jaar nog steeds in een baan onder WOniveau. Bij de gezondheidswetenschappers is dit 54 procent. Zowel economen en gezondheidswetenschappers komen bovendien na een start op WO-niveau in een 
later stadium relatief vaak terecht in een baan waarvoor de werkgever niet expliciet een WO-opleiding vereist (respectievelijk 18 en 20 procent).

Tabel 3.13a

Aansluiting naar richting naar fase in de loopbaan in procenten, cohort 1995-1996

\begin{tabular}{lcc}
\hline & Na één jaar & \\
& Eigen richting & Andere richting \\
\hline Na vijf jaar & & \\
Eigen richting & & \\
Andere richting & 15 & 57 \\
Totaal & 100 & 100 \\
\hline Bron: & & \\
\hline
\end{tabular}

Bron: ROA

Tabel 3.13b

Aansluiting naar richting naar fase in de loopbaan in procenten, cohort 1990-1991

\begin{tabular}{lcc}
\hline & Na één jaar & \\
& & Andere richting \\
& & \\
\hline Na vijf jaar & & \\
Eigen richting & 94 & 71 \\
Andere richting & 6 & 29 \\
Totaal & 100 & 100 \\
Na tien jaar & & \\
Eigen richting & 88 & 73 \\
Andere richting & 12 & 26 \\
Totaal & 100 & 100 \\
& &
\end{tabular}

Bron: ROA

In de tabellen 3.13a en 3.13b wordt gekeken naar de aansluiting tussen de opleidingsrichting en de in de baan vereiste kennis en vaardigheden. Tabel 3.13a laat voor het cohort 1995-1996 zien dat ook hier de start een grote invloed heeft op de aansluiting later in de loopbaan. Meer dan de helft van degenen die buiten het eigen beroependomein startten is na vijf jaar ook buiten het domein werkzaam. Van de groep die na één jaar een baan had verworven die qua richting goed aansloot bij de opleiding is na vijf jaar maar 15 procent uitgeweken naar een baan buiten het eigen domein. Tabel 3.13b laat zien dat het cohort 1990-1991 veel minder vaak buiten het eigen domein is terechtgekomen. Mogelijk is, zoals in hoofdstuk 2 al is gesuggereerd, het karakter van de opleidingen of de arbeidsmarkt zodanig veranderd dat het moeilijker wordt om een passende baan te vinden of juist makkelijker om een baan buiten het eigen domein te vinden. Verder zien we dat tussen de vijf en tien jaar na afstuderen het aandeel van alumni dat buiten het eigen domein werkt nauwelijks meer verandert. Van de starters binnen het eigen domein gaat in de loop der jaren een iets groter deel zijn heil buiten het eigen domein zoeken. Na tien jaar is dit 12 procent. Binnen de starters buiten het eigen domein neemt dit percentage iets af van 29 tot 26 procent. Twee tegengestelde krachten 
kunnen hieraan ten grondslag liggen. Enerzijds komen steeds meer alumni na een zoektocht in een passende baan terecht. Anderzijds waaieren alumni ook steeds meer uit over een breed scala aan functies, bijvoorbeeld managementfuncties.

In tabel 3.14 worden de cijfers uit tabel 3.13b uitgesplitst naar faculteit. De tabel laat zien dat er opmerkelijk geringe verschillen in het loopbaanpatroon zijn, met uitzondering van de faculteit Geneeskunde waar vrijwel alle alumni in een medische functie werkzaam zijn en blijven. De verschillen tussen de overige faculteiten zijn vooral terug te vinden in de groep die na een start in het eigen domein in banen terechtkomt waarin de in de opleiding opgedane kennis en vaardigheden er minder toe doen. Deze groep is voor de faculteiten Economie en Gezondheidswetenschappen veel groter dan voor de juridische faculteit. In hoofdstuk 4 zal dieper op dit vraagstuk worden ingegaan.

Tabel 3.14

Aansluiting naar richting naar fase in de loopbaan en faculteit in procenten, cohort 1990-1991

\begin{tabular}{|c|c|c|c|}
\hline & & \multicolumn{2}{|c|}{ Na één jaar } \\
\hline & & Eigen richting & Andere richting \\
\hline & Na tien jaar & & \\
\hline \multirow[t]{3}{*}{ FdEWB } & Eigen richting & 83 & 75 \\
\hline & Andere richting & 17 & 25 \\
\hline & Totaal & 100 & 100 \\
\hline \multirow[t]{3}{*}{ FdG } & Eigen richting & 96 & - \\
\hline & Andere richting & 4 & - \\
\hline & Totaal & 100 & - \\
\hline \multirow[t]{3}{*}{ FdGW } & Eigen richting & 82 & 74 \\
\hline & Andere richting & 18 & 26 \\
\hline & Totaal & 100 & 100 \\
\hline \multirow[t]{3}{*}{ FdR } & Eigen richting & 93 & 71 \\
\hline & Andere richting & 7 & 29 \\
\hline & Totaal & 100 & 100 \\
\hline
\end{tabular}

Bron: ROA

De beloning is een goede indicator om te illustreren welke groei alumni tijdens hun loopbaan doormaken. Het loon geeft immers een goede indicatie van de waarde van de in de opleiding, via aanvullende scholing en via opgedane ervaring verworven kennis en vaardigheden en van de productiviteit die met deze kennis en vaardigheden wordt gegenereerd. Tabel 3.15 geeft een overzicht van de groei van het bruto uurloon naar cohort en faculteit. De tabel laat zien dat voor het cohort 19951996 in de periode tussen één en vijf jaar na afstuderen de lonen met maar liefst bijna 90 procent zijn gestegen. Voor de economen zijn de lonen zelfs verdubbeld. Voor de medici en de gezondheidswetenschappers was de stijging het kleinst met respectievelijk 68 en 72 procent. 
Uit de tabel blijkt verder dat voor het cohort 1990-1991 de loonstijging in de eerste fase van de loopbaan veel bescheidener was. Dit heeft twee oorzaken. Op de eerste plaats was de inflatie gedurende de eerste helft van de jaren negentig veel geringer dan in de afgelopen vijf jaar. Gedurende de periode 1991-1996 stegen de consumentenprijzen met ruim 10 procent, terwijl de laatste vijf jaar de stijging zo'n 20 procent bedroeg. Bovendien is de krapte op de arbeidsmarkt en daarmee het tekort aan hoger opgeleiden de afgelopen jaren enorm toegenomen, hetgeen zijn weerslag heeft gehad in de beloning. Ook het cohort 1990-1991 heeft van deze krapte geprofiteerd aangezien ook voor hen de lonen enorm zijn gestegen gedurende de afgelopen vijf jaar. Uiteindelijk verdienen alumni na tien jaar ruim 120 procent meer dan één jaar na afstuderen. Gecorrigeerd voor de inflatie is dit een reële stijging van zo'n 90 procent. De lonen van economen zijn het meest gestegen: 157 procent. Medici en juristen zijn twee keer zoveel gaan verdienen.

Tabel 3.15

Groei bruto uurloon in procenten naar cohort en faculteit

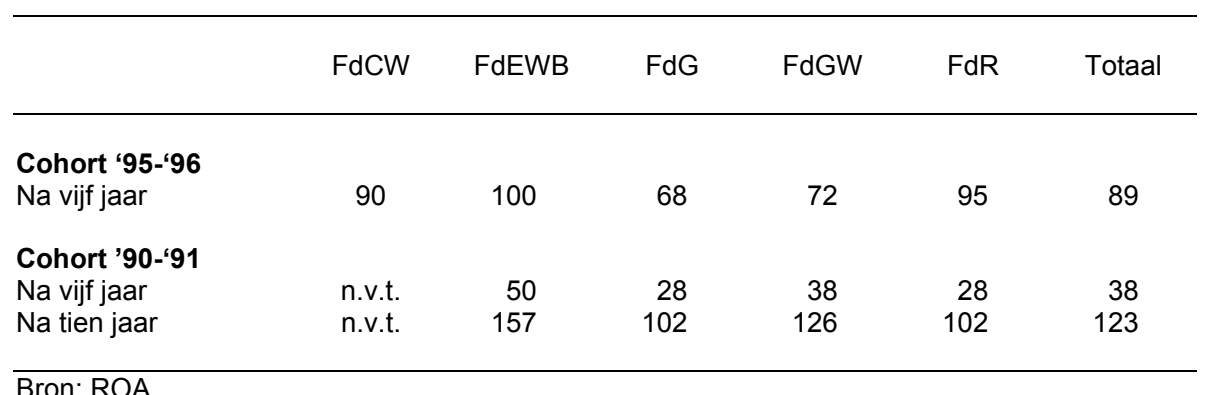

Bron: ROA

Tabel 3.16

Groei bruto uurloon in procenten naar cohort en geslacht

\begin{tabular}{lrrr}
\hline & Mannen & Vrouwen & Totaal \\
\hline $\begin{array}{l}\text { Cohort 1995-1996 } \\
\text { Na vijf jaar }\end{array}$ & 91 & 86 & 89 \\
Cohort 1990-1991 & & & \\
Na vijf jaar & 35 & 42 & 123 \\
Na tien jaar & 107 & 131 & \\
\end{tabular}

Bron: ROA

In tabel 3.16 wordt een overzicht gegeven van de groei van de beloning voor mannen en vrouwen. Binnen het cohort 1995-1996 blijken de lonen voor mannen iets sneller te zijn gestegen dan voor vrouwen (respectievelijk 91 en 86 procent). Het cohort 1990-1991 laat opmerkelijk genoeg het omgekeerde beeld zien. Tussen één en tien jaar na afstuderen stijgen de lonen van vrouwen met 131 procent, terwijl mannen met een stijging van 107 procent genoegen moeten nemen. Allerlei factoren kunnen hierbij een rol spelen. Een belangrijke verklaring zou kunnen zijn dat met name vrouwen kiezen voor een parttime baan. Het is een bekend gegeven dat de beloning per uur in parttime banen gemiddeld hoger is dan in fulltime banen. In 
paragraaf 3 van dit hoofdstuk zal met behulp van een verklarende analyse worden getracht meer inzicht te verschaffen ten aanzien van dit verschil in de groei van het loon tussen mannen en vrouwen. Overigens betekent deze inhaalslag van vrouwen niet dat ze (absoluut gezien) hun achterstand op mannen inhalen. Het verschil wordt echter niet groter: mannen blijken na tien jaar, net als na één jaar, ongeveer $€ 1$,bruto per uur meer te verdienen dan vrouwen.

\subsection{Beloning: een verklarende analyse}

In de voorafgaande paragraaf hebben we gekeken naar allerlei aspecten van het loopbaanpatroon. De nadruk lag daarbij op de impact van de start van de loopbaan op het verdere loopbaanverloop. In deze paragraaf wordt gepoogd het relatieve belang van deze factoren op het loopbaansucces in kaart te brengen met behulp van een verklarende analyse van het bruto uurloon vijf jaar na afstuderen. Er zijn twee modellen geschat. Model $A$ is een 'traditioneel' model waarin de beloning wordt verklaard vanuit een aantal persoons- en baankenmerken. In model B worden aan deze persoons- en baankenmerken een aantal indicatoren voor de arbeidsmarktpositie tijdens de start van de loopbaan toegevoegd. De resultaten worden gepresenteerd in tabel 3.17 .

Model A laat zien dat mannen niet significant meer verdienen dan vrouwen. Dit resultaat sluit heel goed aan bij de in paragraaf 3.2 gepresenteerde cijfers. Daar zagen we dat het verschil in beloning tussen mannen en vrouwen gedurende de verdere loopbaan zich min of meer stabiliseert. De leeftijd blijkt in beperkte mate van belang. De oudere alumnus verdient significant meer dan de jongere UM'er. De samenstelling van het huishouden blijkt er niet toe te doen. Het al dan niet hebben van kinderen of een partner heeft geen significant effect op de beloning. Gezondheidswetenschappers en vooral juristen blijken na vijf jaar significant minder te verdeinen dan economen. De prestaties tijdnes de opleiding - waarvoor het gemiddeld eindcijfer hier als indicator wordt gebruikt - blijkt er na vijf jaar niet (meer) toe te doen.

Het is niet verrassend dat AIO's significant minder verdienen dan alumni in 'normale' loondienst. UM'ers die een eigen bedrijf zijn begonnen, blijken significant meer inkomsten te hebben. Het baanniveau blijkt een zeer belangrijke invloed te hebben op de beloning. UM'ers die werkzaam zijn in banen waarin kennis en vaardigheden op academisch niveau worden vereist, worden significant beter beloond dan UM'ers die onder WO-niveau werkzaam zijn. De aansluiting naar richting blijkt er daarentegen niet toe te doen. Alumni die werkzaam zijn in een baan waarin de eigen of een verwante opleiding wordt vereist verdienen niet significant meer dan alumni die buiten hun eigen domein emplooi gevonden hebben. Naast het aanwenden van kennis en vaardigheden op academisch niveau, worden ook leidinggevende taken door de werkgever beloond. De alumnus die werkzaam is in een leidinggevende functie verdient significant meer dan de alumnus die geen leiding hoeft te geven. 
Tabel 3.17

Een verklarende analyse van het bruto uurloon na vijf jaar, cohort 1995-1996

\begin{tabular}{|c|c|c|c|c|}
\hline & \multicolumn{2}{|c|}{ Model A } & \multicolumn{2}{|c|}{ Model B } \\
\hline & Coëfficiënt & t-waarde & Coëfficiënt & t-waarde \\
\hline Constante & 2,394 & $15,87^{\star \star *}$ & 1,994 & $11,02^{* * *}$ \\
\hline Man & 0,047 & 1,13 & 0,032 & 0,77 \\
\hline Leeftijd & 0,008 & $1,86^{*}$ & 0,005 & 1,09 \\
\hline \multicolumn{5}{|l|}{ Samenstelling huishouden } \\
\hline $\begin{array}{l}\text { Samenwonend met kinderen } \\
\text { Samenwonend zonder kinderen }\end{array}$ & $\begin{array}{l}0,057 \\
\text { referentie }\end{array}$ & 1,21 & $\begin{array}{c}0,064 \\
\text { referentie }\end{array}$ & 1,40 \\
\hline Alleenstaand & 0,033 & 0,70 & 0,023 & 0,51 \\
\hline \multicolumn{5}{|l|}{ Studie } \\
\hline $\begin{array}{l}\text { FdCW } \\
\text { FdEWB }\end{array}$ & $\begin{array}{l}-0,113 \\
\text { referentie }\end{array}$ & $-0,95$ & $\begin{array}{l}-0,096 \\
\text { referentie }\end{array}$ & $-0,83$ \\
\hline $\mathrm{FdG}$ & $-0,115$ & $-1,64$ & $-0,142$ & $-1,99^{* *}$ \\
\hline FdGW & $-0,126$ & $-2,38^{* *}$ & $-0,112$ & $-2,16^{\star *}$ \\
\hline FdR & $-0,199$ & $-3,68^{* * *}$ & $-0,205$ & $-3,83^{* * *}$ \\
\hline Gemiddeld eindcijfer $>7$ & $-0,003$ & $-0,08$ & $-0,008$ & $-0,24$ \\
\hline \multicolumn{5}{|l|}{ Dienstverband } \\
\hline $\mathrm{AlO}$ & $-0,414$ & $-2,76^{\star \star *}$ & $-0,447$ & $-3,04^{* * *}$ \\
\hline Eigen bedrijf & 0,498 & $4,26^{* * *}$ & 0,508 & $4,46^{\star \star \star}$ \\
\hline Loondienst / freelance & referentie & & referentie & \\
\hline \multicolumn{5}{|l|}{ Baankenmerken } \\
\hline Werkzaam op WO-niveau & 0,207 & $5,08^{* * *}$ & 0,176 & $4,18^{* * *}$ \\
\hline Werkzaam in eigen richting & $-0,009$ & $-0,22$ & $-0,000$ & $-0,01$ \\
\hline Parttime baan & 0,147 & $2,99^{* * *}$ & 0,143 & $3,00^{* * *}$ \\
\hline Leidinggevende functie & 0,082 & $2,28^{* *}$ & 0,078 & $2,22^{* * *}$ \\
\hline Bedrijf > 100 personen & 0,143 & $3,14^{* * *}$ & 0,143 & $3,23^{* * *}$ \\
\hline Vaste aanstelling & 0,078 & 1,53 & 0,069 & 1,37 \\
\hline Non-profit instelling & $-0,011$ & $-0,24$ & $-0,022$ & $-0,48$ \\
\hline \multicolumn{5}{|l|}{ Arbeidsmarktpositie na één jaar } \\
\hline Logaritme bruto uurloon & & & 0,217 & $3,25^{\text {*** }}$ \\
\hline Werkzaam op WO-niveau & & & 0,111 & $2,67^{* * *}$ \\
\hline Werkzaam in eigen richting & & & $-0,041$ & $-0,88$ \\
\hline Vaste aanstelling & & & $-0,009$ & $-0,25$ \\
\hline $\mathrm{N}$ & 273 & & 273 & \\
\hline Gecorrigeerde R-kwadraat & 0,254 & & 0,299 & \\
\hline
\end{tabular}

Alumni in een parttime baan worden per uur gemiddeld beter beloond dan alumni met een volledige werkweek. Dit is een bekend resultaat, dat mogelijk wordt veroorzaakt door een negatieve relatie tussen de omvang van de werkweek en de productiviteit. Naarmate men meer werkt, wordt de gemiddelde productiviteit per uur mogelijk lager. Het hebben van een vaste aanstelling heeft geen significant effect. Mogelijk heeft al dan niet hebben van een vaste aanstelling na een aantal jaren niet zozeer meer te maken de kwaliteit (en daarmee de productiviteit) van de arbeidskracht, maar veel meer met het type functie. Alumni die werkzaam zijn in een 
groot bedrijf verdienen significant meer dan degenen die emplooi hebben gevonden in een bedrijf waarin minder dan 100 mensen werkzaam zijn. Mogelijk zijn de scholingsmogelijkheden, waarmee werknemers hun productiviteit kunnen vergroten, in grote bedrijven beter. Een andere verklaring zou kunnen zijn dat het in grote bedrijven makkelijker is het takenpakket perfect af te stemmen op de kennis en vaardigheden van de werknemer.

Model B onderscheidt zich van model A doordat er een aantal indicatoren voor de arbeidsmarktpositie tijdens de start van de loopbaan (zo'n anderhalf jaar na afstuderen) zijn toegevoegd. Hiermee kunnen de effecten van een al dan niet succesvolle start op het verdere verloop van de loopbaan worden geanalyseerd.

Model B blijkt significant beter te zijn dan model A. ${ }^{1}$ Uit de tabel blijkt dat het loon één jaar na afstuderen een significant effect heeft op het loon na vijf jaar. Met andere woorden: een hoge beloning aan het begin van de loopbaan heeft een belangrijke voorspellende waarde voor de groei van het loon in de daarop volgende vier jaar. Dit wil overigens niet zeggen dat er sprake is van een causaal verband. Het effect kan ook worden toegeschreven aan het feit dat zowel het loon na één als na vijf jaar door dezelfde (ongemeten) achtergrondfactoren worden bepaald. Hiermee biedt model $B$ een correctie voor verborgen heterogeniteit, ervan uitgaande dat deze heterogeniteit zich inderdaad manifesteert in het loon dat één jaar na afstuderen wordt verdiend.

Naast de beloning heeft ook de aansluiting één jaar na afstuderen een significant effect op het loon na vijf jaar. Dit betekent dat een functie op WO-niveau tijdens de start van de loopbaan een succesvolle verdere loopbaan bevordert. Omgekeerd heeft een start in een functie beneden WO-niveau - ook wanneer na vijf jaar inmiddels een functie op WO-niveau is verworven - nog altijd een effect op het loon. De werkgever waardeert blijkbaar de werkervaring die is opgedaan op academisch niveau. In het begin van de loopbaan werkzaam zijn in een functie binnen het eigen beroependomein heeft geen effect op de latere beloning. Ook het hebben van een vaste aanstelling speelt geen rol.

Wanneer we de resultaten van model B vergelijken met die van model A zien we dat het leeftijdseffect niet meer significant is. Dit betekent dat de loongroei niet leeftijdsafhankelijk is. Leeftijd speelt vooral een rol bij het startloon. De juristen blijken er - in vergelijking met de economen - nog steeds in negatieve zin uit te springen. Juristen hebben dus niet zozeer of niet alleen bij de start van de loopbaan, maar ook in de daarop volgende jaren problemen om de loongroei van economen bij te benen. Ook de medici en gezondheidswetenschappers blijven qua beloning achter bij de economen.

Het effect van het werken op WO-niveau blijft significant. Dit impliceert dat niet alleen de start in een academische functie loont. Ook tussen één en vijf jaar na afstuderen wordt het emplooi vinden in een baan op WO-niveau beloond met een grotere

1. Een F-test laat zien dat de door model $B$ verklaarde variantie significant groter is $(F=5,14$. Dit is significant bij $\alpha=0,01$ ). 
loonstijging dan wanneer de UM'er werkzaam is in een baan onder zijn of haar niveau. Ook de effecten van een parttime baan en leidinggeven blijven significant. Dit laatste is niet verrassend. In hoofdstuk 2 hebben we gezien dat UM'ers vooral leidinggevende taken krijgen na de start van hun loopbaan. Na één jaar zal een bonus op basis van leidinggevende taken nauwelijks zichtbaar zijn. Ook het werken in een groot bedrijf blijft lonend.

\subsection{Conclusie}

UM'ers die vijf jaar geleden zijn afgestudeerd hebben gemiddeld bijna 3 banen gehad. Voor de UM'ers die de universiteit tien jaar geleden hebben verlaten, is dit aantal met 3,3 maar weinig hoger. Dit geringe verschil kan twee oorzaken hebben. Enerzijds komen loopbanen na een aantal jaren in een rustiger vaarwater. Anderzijds kunnen cohorteffecten een rol spelen. Zo kan de arbeidsmarktsituatie invloed hebben op de mobiliteit. De gedwongen mobiliteit zal geringer zijn wanneer de arbeidsmarkt gekenmerkt wordt door een grote krapte. Een tekort aan personeel kan daarentegen een positief effect hebben op de vrijwillige mobiliteit, omdat er meer mogelijkheden zijn om de positie te verbeteren. De verschillen tussen de faculteiten zijn opmerkelijk gering. Juristen lijken het minst mobiel, terwijl medici en alumni van de faculteit Cultuur en Wetenschapsstudies het vaakst van baan wisselen. In hoofdstuk 2 hebben we gezien dat juist deze twee groepen het meeste moeite hebben een vaste baan te verwerven. Zeer stabiele loopbanen (slechts één baan) of turbulente loopbanen ( 5 of meer banen) zijn relatief schaars. Zo heeft van de alumni die tien jaar geleden zijn afgestudeerd slechts 8 procent maar één baan gehad, terwijl ruim 20 procent vijf of meer banen heeft gehad. Het aantal werkgevers loopt over het algemeen aardig in de pas met het aantal banen. Een baanverandering betekent dus in veel gevallen een verandering van werkgever. Bij alumni van de faculteit Cultuur en Wetenschapsstudies is het verschil het grootst. Alumni van deze faculteit wisselen dus blijkbaar relatief vaak bij dezelfde werkgever van baan.

Gemiddeld maakt slechts de helft van de Maastrichtse alumni een periode van werkloosheid mee. De verschillen tussen de faculteiten zijn te verwaarlozen. Dit gunstige beeld wordt ook weerspiegeld door het feit dat slechts ruim 6 procent van de Maastrichtse alumni vaker dan één keer werkloos is (geweest) gedurende zijn of haar loopbaan. Bovendien heeft slechts zo'n 10 procent van de Maastrichtse alumni vaker dan één keer onvrijwillig een baan moeten verlaten. Geconcludeerd kan worden door een overgrote deel van de mobiliteit van Maastrichtse alumni een vrijwillig karakter heeft.

Alumni starten relatief vaak in een tijdelijke baan. Na vijf jaar blijkt zo'n start in een tijdelijke baan nog steeds merkbaar. Van degenen uit het cohort 1995-1996 die na één jaar een vaste baan hadden verworven, werkt na vijf jaar slechts 7 procent met een tijdelijk contract. Voor degenen die na één jaar een tijdelijke aanstelling hadden, is dit meer dan 20 procent. Voor het cohort 1990-1991 is dit effect nog beter zichtbaar. $\mathrm{Na}$ vijf jaar heeft slechts 59 procent van de alumni die na één jaar een tijdelijk contract hadden, een vaste baan verworven. Medici zijn voor een belangrijk deel verantwoordelijk voor het effect van een geringe baanzekerheid na één jaar op 
het al dan niet hebben van een vast contract na vijf jaar. Bij de juristen, economen en gezondheidswetenschappers is het effect weliswaar aanwezig, maar veel kleiner. Geconcludeerd kan worden dat over het algemeen slechts een kleine groep de gevolgen van een geringe baanzekerheid aan het begin van de loopbaan na vijf jaar nog steeds ondervindt. Bovendien blijkt dit effect na tien jaar volledig te zijn verdwenen. Meer dan 80 procent van de alumni heeft een vaste baan, ongeacht de baanzekerheid in de loopbaan tot dan toe.

Niet alleen de duur van de aanstelling, ook het baanniveau bij de start van de loopbaan heeft invloed op het verdere loopbaanverloop. Ruim de helft (52 procent) van de alumni uit het cohort 1995-1996 die beneden WO-niveau startten, werkt na vijf jaar nog steeds beneden zijn of haar niveau. Voor het cohort 1990-1991 blijkt onderbenutting ook na tien jaar een hardnekkig fenomeen te zijn. Alumni die na één jaar beneden WO-niveau werkzaam waren, zijn na tien jaar nog steeds relatief vaak onder hun niveau werkzaam (45 procent). Vooral economen en gezondheidswetenschappers zijn hiervoor verantwoordelijk. Maar liefst 58 procent van de onder hun niveau startende economen werkt na vijf jaar nog steeds in een baan onder WOniveau. Bij de gezondheidswetenschappers is dit 54 procent. Ook ten aanzien van de aansluiting naar richting heeft de start grote gevolgen voor de rest van de loopbaan. Meer dan de helft van degenen die buiten het eigen beroependomein startten is na vijf jaar ook buiten het domein werkzaam. Van de groep die na één jaar een baan had verworven die qua richting goed aansloot bij de opleiding is na vijf jaar maar 15 procent uitgeweken naar een baan buiten het eigen domein. Verder zien we dat tussen de vijf en tien jaar na afstuderen het aandeel van alumni dat buiten het eigen domein werkt nauwelijks meer verandert. De verschillen tussen de faculteiten zijn opmerkelijk gering, met uitzondering van de faculteit Geneeskunde waarvan de alumni vrijwel allemaal binnen hun eigen richting starten en gedurende het vervolg van hun loopbaan werkzaam blijven.

Voor het cohort 1995-1996 geldt dat bijna de helft van degenen die na één jaar parttime werkten, dat na vijf jaar nog steeds doet. Van de groep die na één jaar een volledige aanstelling had, werkt slechts 21 procent in deeltijd. Het cohort 1990-1991 laat zien dat ook na tien jaar weinig is veranderd. Bijna de helft (47 procent) van de alumni die na één jaar in deeltijd werkten, doet dat na tien jaar ook. Deze groep wordt zelfs in de loop der jaren weer groter. Na vijf jaar blijkt namelijk tweederde van de parttime starters fulltime te werken. Zo'n 15 procent van de parttime starters komt dus tussen de vijf en tien jaar na afstuderen opnieuw in een parttime baan terecht. De verschillen tussen mannen en vrouwen zijn groot. Daar waar mannen, ook wanneer ze in een parttime baan gestart zijn, na vijf en tien jaar meest een volledige werkweek hebben, kiezen vrouwen veel vaker voor een parttime aanstelling. Na tien jaar is het verschil tussen vrouwelijke parttime en fulltime starters relatief klein geworden. Dit wijst erop dat vrouwen - vooral vanwege de zorg voor kinderen vrijwillig kiezen voor een parttime baan.

De beloning is een goede indicator om te illustreren welke groei alumni tijdens hun loopbaan doormaken. Voor het cohort 1995-1996 zijn in de periode tussen één en vijf jaar na afstuderen de lonen met maar liefst bijna 90 procent gestegen. Voor de 
economen zijn de lonen zelfs verdubbeld. Voor de medici en de gezondheidswetenschappers was de stijging het kleinst met respectievelijk 68 en 72 procent. Voor het cohort 1990-1991 was de loonstijging in de eerste fase van de loopbaan veel bescheidener, vanwege de geringere inflatie en de minder krappe arbeidsmarkt voor hoger opgeleiden in de eerste helft van de jaren negentig. Ook voor het cohort 1990-1991 zijn de lonen echter enorm gestegen gedurende de afgelopen vijf jaar. Uiteindelijk verdienen alumni na tien jaar ruim 120 procent meer dan één jaar na afstuderen. Gecorrigeerd voor de inflatie is dit een reële stijging van zo'n 90 procent. De lonen van economen zijn het meest gestegen: 157 procent. Medici en juristen zijn twee keer zoveel gaan verdienen. Vrouwen maken een inhaalslag gedurende de loopbaan; het uurloon van vrouwen stijgt sneller dan dat van mannen. Deze inhaalslag van vrouwen betekent niet dat ze (absoluut gezien) hun achterstand op mannen inhalen. Het verschil wordt echter niet groter: mannen blijken na tien jaar, net als na één jaar, ongeveer $€ 1$,- bruto per uur meer te verdienen dan vrouwen.

De start van de loopbaan blijkt een significant effect te hebben op het loopbaansucces. Uit een verklarende loonanalyse blijkt dat het loon één jaar na afstuderen een belangrijk significant effect heeft op de beloning na vijf jaar. Met andere woorden: een hoge beloning aan het begin van de loopbaan heeft een belangrijke voorspellende waarde voor de groei van het loon in de daarop volgende vier jaar. Dit wil overigens niet zeggen dat er sprake is van een causaal verband. Het effect kan ook worden toegeschreven aan het feit dat zowel het loon na één als na vijf jaar door dezelfde (ongemeten) achtergrondfactoren worden bepaald.

Naast de beloning heeft ook de aansluiting één jaar na afstuderen een significant effect op het loon na vijf jaar. Dit betekent dat een functie op WO-niveau tijdens de start van de loopbaan een succesvolle verdere loopbaan bevordert. Omgekeerd heeft een start in een functie beneden WO-niveau - ook wanneer na vijf jaar inmiddels een functie op WO-niveau is verworven - nog altijd een effect op het loon. De werkgever waardeert blijkbaar de werkervaring die is opgedaan op academisch niveau. Daarnaast is ook het effect van het werken op WO-niveau na vijf jaar significant. Dit impliceert dat niet alleen de start in een academische functie loont. Ook tussen één en vijf jaar na afstuderen wordt het emplooi vinden in een baan op WO-niveau beloond met een grotere loonstijging dan wanneer de UM'er werkzaam is in een baan onder zijn of haar niveau. In het begin van de loopbaan werkzaam zijn in een functie binnen het eigen beroependomein heeft geen effect op de latere beloning. Ook het hebben van een vaste aanstelling speelt geen rol. 


\section{De aansluiting tussen beroep en opleiding}

Dit hoofdstuk heeft een thematisch karakter. De relatie tussen opleiding en beroep en de daaraan nauw gerelateerde aansluitingsproblematiek staan in dit hoofdstuk centraal. In het onderzoek naar de transitie van school naar werk ligt de nadruk op de gevolgen van een niet optimale aansluiting voor het functioneren in de baan. Hierbij wordt er impliciet vanuit gegaan dat de afgestudeerde beter zal functioneren in een baan die inhoudelijk goed aansluit bij de in de opleiding verworven kennis en vaardigheden. Met andere woorden: de mate waarin alumni in staat zijn een baan te vinden die goed aansluit op de opleiding, vormt een goede indicator voor een succesvolle start van de loopbaan. De vraag is hoe dit beeld er later in de loopbaan uitziet. Is een goede inhoudelijke aansluiting tussen opleiding en beroep nog steeds zo belangrijk als bij de start op de arbeidsmarkt? Of kan een loopbaanpad dat afwijkt van het 'reguliere' pad ook een goede optie zijn? De nadruk ligt in dit hoofdstuk niet zozeer op het niveau, maar op de inhoud van de verworven kennis en vaardigheden in de opleiding en de vereiste kennis en vaardigheden in de baan. ${ }^{2}$

De opzet van dit hoofdstuk is als volgt. Paragraaf 1 brengt de aansluiting tussen opleidingsrichting en beroep in kaart vanuit verschillende invalshoeken. Hierbij wordt aandacht geschonken aan de omvang van het fenomeen buiten het eigen beroependomein werken, de redenen om dat te doen, de beroepen waarin alumni van de verschillende faculteiten terechtkomen en de dynamiek in het al dan niet buiten het eigen domein werkzaam zijn. In paragraaf 2 wordt ingegaan op de gevolgen van het hebben van een baan die minder goed aansluit op de gevolgde opleiding. Er wordt met name gekeken naar de gevolgen voor de beloning en de werksatisfactie.

\subsection{De aansluiting tussen opleidingsrichting en beroep in kaart}

Een goed startpunt voor het in kaart brengen van de aansluiting tussen opleidingsrichting en beroep is logischerwijs de vraag in hoeverre UM'ers vaak een baan (moeten) kiezen die minder goed aansluit op de opleidingsrichting. Tabel 4.1 laat zien dat zo'n 20 procent van de alumni uit het cohort 1995-1996 emplooi vindt in een baan die buiten de eigen opleidingsrichting valt. Dit percentage is na vijf jaar met $23 \%$ iets groter. $^{3}$ Deze toename wordt veroorzaakt door het feit dat de groep die buiten de eigen richting werkzaam is, maar wel een baan op WO-niveau heeft verworven. De groep die zowel buiten de eigen richting en beneden WO-niveau werkzaam is neemt iets af van 14 tot 12 procent. Dit is een eerste aanwijzing dat het

2. Bovendien wordt in dit hoofdstuk gekozen voor analyses met data van het cohort 19951996. Het cohort 1990-1991 is helaas te klein om met de gedetailleerde analyses in dit hoofdstuk betrouwbare resultaten te presenteren.

3. De cijfers die betrekking hebben op de situatie na vijf jaar zijn ook gepresenteerd in tabel 2.7. De hier gepresenteerde cijfers wijken iets af. Dit heeft te maken met enigszins afwijkende onderzoekspopulatie. In hoofdstuk 2 zijn alle respondenten uit het cohort 19951996 die in 2002 de vragenlijst hebben ingevuld geanalyseerd. In dit hoofdstuk wordt de onderzoekspopulatie gevormd door degenen die zowel in 1997 als in 2002 de vragenlijst hebben ingevuld. 
buiten eigen domein werkzaam zijn niet zozeer een verzwakking van de arbeidsmarktpositie hoeft te betekenen, maar ook een bewuste keuze kan zijn.

Tabel 4.1

Aansluiting naar niveau en richting in procenten, cohort 1995-1996

\begin{tabular}{lcc}
\hline & Na één jaar & Na vijf jaar \\
\hline Op niveau en in eigen richting & 54 & 59 \\
Op niveau en buiten eigen richting & 6 & 11 \\
Onder niveau en in eigen richting & 26 & 18 \\
Onder niveau en buiten eigen richting & 14 & 12 \\
& &
\end{tabular}

Bron: ROA

In de rest van dit hoofdstuk richten we ons op de alumni die een baan op WO-niveau hebben verworven. De impliciete veronderstelling daarbij is dat alleen op WO-niveau een loopbaanpad dat afwijkt van het 'reguliere' pad ook een goede optie kan zijn. In tabel 4.1 zagen we dat 60 procent van de alumni uit het cohort 1995-1996 na één jaar op WO-niveau werkzaam was. Bovendien zagen we dat 6 procent op WOniveau buiten de eigen richting werkzaam was. Met andere woorden: 10 procent van degenen die na één jaar een baan op WO-niveau had verworven, was buiten de eigen richting werkzaam. Dit percentage zien we terug in tabel 4.2. Uit de tabel blijkt ook dat dit percentage na vijf jaar is gestegen tot 16 procent. Deze toename doet zich bij alle faculteiten voor. De toename is het sterkst onder de gezondheidswetenschappers. Na één jaar heeft slechts 5 procent voor een baan buiten het eigen beroependomein gekozen; na vijf jaar is dit percentage gestegen tot 16 procent. Juristen waaieren het vaakst uit over beroepen buiten het eigen domein. Medici zijn het vaakst werkzaam in een baan waarvoor de eigen of een verwante opleiding door de werkgever wordt vereist. Naarmate de loopbaan vordert neemt bovendien het aantal medici dat buiten het eigen beroependomein werkt nauwelijks toe.

Tabel 4.2

Een andere of geen specifieke richting vereist door de werkgever naar faculteit, cohort 19951996

\begin{tabular}{lccccc}
\hline & FdEWB & FdG & FdGW & FdR & Totaal \\
\hline Na één jaar & 13 & 3 & 5 & 18 & 10 \\
Na vijf jaar & 17 & 4 & 16 & 19 & 16 \\
\hline
\end{tabular}

Bron: ROA

In de tabellen 4.1 en 4.2 hebben we gezien dat UM'ers na een aantal jaren wat vaker buiten hun eigen vakgebied terechtkomen. De vraag rijst nu hoe de dynamiek in deze verschuiving eruit ziet. Is er sprake van een harde kern van UM'ers die buiten de eigen richting werkt; een harde kern die in de loop der jaren wat groter wordt? Of keert tegelijkertijd een groot aantal UM'ers na een start buiten de eigen richting in de loop der jaren terug naar het eigen beroependomein? In tabel 4.3 wordt gekeken 
naar die UM'ers die gedurende de eerste vijf jaar van hun loopbaan voortdurend op WO-niveau werkzaam zijn geweest. De tabel laat zien dat 90 procent van de groep die na één jaar binnen de eigen richting werkzaam was, na vijf jaar nog steeds een functie heeft die goed aansluit bij de gevolgde opleiding. De tabel laat echter ook zien dat meer dan helft van degenen die buiten hun eigen beroependomein zijn gestart, later een baan vindt die wel goed aansluit bij de opleiding. Dit impliceert dat er weliswaar een groep is die vanaf de start buiten zijn eigen richting emplooi vindt, maar dat de groei van het aantal UM'ers dat buiten de eigen richting werkzaam is naarmate de loopbaan vordert vooral gezocht moet worden bij de 10 procent die later in de loopbaan uitwaaiert over beroepen buiten het eigen domein.

Tabel 4.3

Aansluiting naar richting naar fase in de loopbaan in procenten, cohort 1995-1996

\begin{tabular}{lcc}
\hline & Na één jaar & \\
& Eigen richting & Andere richting \\
\hline Na vijf jaar & & \\
Eigen richting & 90 & 55 \\
Andere richting & 10 & 45 \\
Totaal & 100 & 100 \\
\hline
\end{tabular}

Bron: ROA

Tabel 4.4

Aansluiting naar richting naar fase in de loopbaan en faculteit in procenten, cohort 1995-1996

\begin{tabular}{|c|c|c|c|}
\hline & & \multicolumn{2}{|c|}{ Na één jaar } \\
\hline & & Eigen richting & Andere richting \\
\hline & Na vijf jaar & & \\
\hline \multirow[t]{3}{*}{ FdEWB } & Eigen richting & 90 & 60 \\
\hline & Andere richting & 10 & 40 \\
\hline & Totaal & 100 & 100 \\
\hline \multirow[t]{3}{*}{ FdG } & Eigen richting & 97 & 100 \\
\hline & Andere richting & 3 & 0 \\
\hline & Totaal & 100 & 100 \\
\hline \multirow[t]{3}{*}{ FdGW } & Eigen richting & 90 & 45 \\
\hline & Andere richting & 10 & 55 \\
\hline & Totaal & 100 & 100 \\
\hline \multirow[t]{3}{*}{ FdR } & Eigen richting & 90 & 58 \\
\hline & Andere richting & 10 & 42 \\
\hline & Totaal & 100 & 100 \\
\hline
\end{tabular}

\section{Bron: ROA}

In tabel 4.4 worden de cijfers uit tabel 4.3 uitgesplitst naar faculteit. Ten aanzien van de groep die start in een baan die goed aansluit op de gevolgde opleiding, zijn de verschillen opmerkelijk gering. Zo'n 10 procent stapt later over naar een baan buiten het eigen domein. Alleen de medici wijken enigszins af van dit beeld. Slechts 3 
procent van de medici kiest voor een voortzetting van de loopbaan buiten het eigen domein. We zagen dan ook al in tabel 4.2 dat, naarmate de loopbaan vordert, het aantal medici dat buiten het eigen beroependomein werkt nauwelijks toeneemt. Ten aanzien van de groep die buiten de eigen richting zijn of haar loopbaan start, is het beeld wat gevarieerder. Met name voor gezondheidswetenschappers betekent een start buiten het eigen domein dat ze niet meer terugkeren naar een baan die goed aansluit op de opleiding. Meer dan de helft (55 procent) is ook na vijf jaar in een baan werkzaam waarvoor de werkgever geen of een geheel andere opleiding vereist. Bij de andere faculteiten is dit percentage aanzienlijk kleiner dan 50 procent.

Tabel 4.5

Redenen om voor een baan buiten het eigen domein te kiezen, cohort 1995-1996

Ik ben er (nog) niet in geslaagd een passende baan te vinden

Deze baan geeft betere carrièremogelijkheden $\quad 26$

Ik werk liever buiten mijn vakgebied

Ik kreeg promotie naar een baan buiten mijn vakgebied

Ik kan meer verdienen in deze baan

Ik heb meer werkzekerheid in deze baan

Deze baan stelt mij in staat om in deeltijd of met flexibele werktijden te werken 13

Ik heb een voorkeur voor deze regio

Deze baan kan ik makkelijker verenigen met mijn gezinssituatie

Ik vind dit (ook) interessant werk

Anders

Bron: ROA

Centraal in dit hoofdstuk staat de vraag in hoeverre het afwijken van het 'reguliere' loopbaanpad een vanuit het oogpunt van de arbeidsmarktpositie aantrekkelijke optie kan zijn. De reden om voor een baan buiten het eigen beroependomein te kiezen kan hiervoor een goede indicator zijn. Tabel 4.5 geeft een overzicht van de argumenten om buiten de eigen richting emplooi te zoeken. Het gaat hierbij om de argumenten die door de alumni worden genoemd voor de keuze van de baan die zij vijf jaar na afstuderen hebben. ${ }^{4}$ De tabel laat zien dat het vaak inhoudelijke factoren zijn die tot de keuze hebben geleid. Bijna 40 procent geeft aan liever buiten het eigen vakgebied te werken. Daarnaast geeft 16 procent aan het werk buiten het eigen vakgebied ook interessant te vinden. Een tweede belangrijk element wordt gevormd door factoren die te maken hebben met de arbeidsmarktpositie. Met name de betere carrièremogelijkheden ( 26 procent) worden hier vaak genoemd. Ook de betere verdiensten (10 procent), de grotere werkzekerheid (10 procent) en een promotie ( 7 procent) kunnen worden beschouwd als arbeidsmarktgerelateerde factoren. Een derde factor zijn privé-omstandigheden zoals de mogelijkheid in deeltijd te werken, een voorkeur voor de regio en de mogelijkheid het werk te combineren met het gezin. De privéomstandigheden blijken echter voor relatief weinig UM'ers een drijfveer te zijn een baan buiten de eigen richting te zoeken. Waarschijnlijk bieden ook banen binnen de

4. De respondenten mochten meerdere redenen tegelijk aangeven. De percentages tellen daarom niet op tot 100 procent. 
eigen richting de mogelijkheid het werk af te stemmen op deze privé-omstandigheden. Slechts 13 procent geeft ten slotte aan (nog) geen passende baan gevonden te hebben. Aan dit lage percentage ligt mede de krapte op de arbeidsmarkt ten grondslag. Deze krapte heeft ertoe geleid dat veel hoog opgeleiden een baan hebben kunnen vinden die goed aansluit bij hun capaciteiten en voorkeuren. Er mag worden geconcludeerd dat veel UM'ers een positieve keuze maken voor een baan buiten het eigen vakgebied, aangezien het vaak gaat om een inhoudelijke keuze of een verbetering van het carrièreperspectief.

Naast de reden om buiten de eigen richting te gaan werken, kan ook het beroep inzicht verschaffen over de drijfveren achter deze keuze. In tabel 4.6 wordt een overzicht gegeven van de beroepen waarin UM'ers buiten hun eigen vakgebied werkzaam zijn. ${ }^{5}$ De tabel laat een gevarieerd beeld zien. Toch kunnen er een aantal conclusies worden getrokken. Ten eerste komen UM'ers relatief vaak in min of meer verwante beroepen terecht. De econoom wordt bijvoorbeeld commercieel medewerker en de gezondheidswetenschapper wordt (of blijt) therapeut of verpleegkundige. Ten tweede biedt de ICT-sector voor de UM'er een mogelijkheid zijn horizon te verbreden. Ten derde komen UM'ers na vijf jaar in managementfuncties terecht.

Tabel 4.6

Alumni buiten hun eigen beroependomein

\begin{tabular}{|c|c|c|}
\hline FdEWB & FdGW & $\mathrm{FdR}$ \\
\hline Technisch systeemanalist & $\begin{array}{l}\text { Therapeut of } \\
\text { verpleegkundige }\end{array}$ & Assistent accountant \\
\hline Commercieel medewerker & Systeemanalist & Commercieel medewerker \\
\hline Sociaal-cultureel werker & $\begin{array}{l}\text { Onderwijskundige of } \\
\text { pedagoog }\end{array}$ & Arts \\
\hline Leidinggevende & Arts & Organisatiedeskundige \\
\hline Econoom & Organisatiedeskundige & Jurist \\
\hline Organisatiedeskundige & Informaticus & $\begin{array}{l}\text { Sociaal-wetenschappelijk } \\
\text { onderzoeker }\end{array}$ \\
\hline $\begin{array}{l}\text { Informaticus } \\
\text { Sociaal raadsman of } \\
\text { hoofd personeelszaken } \\
\text { Manager }\end{array}$ & Manager & Manager \\
\hline
\end{tabular}

Bron: ROA

In tabel 4.5 zagen we dat de UM'er twee belangrijke argumenten noemt om buiten zijn eigen richting werk te zoeken: inhoudelijke voorkeur en loopbaanperspectief. Deze twee argumenten zien we ook hier terug. Zo kiest de jurist uit inhoudelijke interesse voor het onderzoekerschap en wordt de econoom sociaal-cultureel werker. UM'ers worden manager of kiezen voor de ICT-sector vanwege het betere loopbaanperspectief.

5. Gezien de omvang van de groep, heeft dit beroepenoverzicht een enigszins arbitrair karakter. Vandaar dat deze tabel vooral als een illustratie beschouwd moet worden en er daarom geen percentages worden gepresenteerd. Voor de medici geldt dat slechts twee respondenten een beroep hebben aangegeven. In beide gevallen gaat het hier om een functie als arts. 
Persoonlijke voorkeuren of de situatie op de arbeidsmarkt kunnen ertoe leiden dat mensen in een baan buiten hun eigen richting terechtkomen. Via een verklarende analyse van de kans dat iemand in een baan in de eigen richting terechtkomt is gepoogd meer inzicht te verwerven in de factoren die hieraan ten grondslag liggen. De resultaten van deze analyse worden gepresenteerd in tabel 4.7. Na één jaar bleek het vooral de opleiding te zijn die bepaalde of alumni al dan niet binnen hun eigen vakrichting werkzaam waren. Economen en juristen kwamen significant minder vaak in hun eigen richting terecht dan medici. Als gevolg van de meer beroepsgerichte kennis en vaardigheden en mogelijk als gevolg van de arbeidsmarktsituatie kwamen medici dus vaker in hun eigen beroependomein terecht. Datzelfde gold voor gezondheidswetenschappers. De resultaten laten immers zien dat zij niet significant minder vaak in hun eigen richting werkzaam waren dan medici.

Tabel 4.7

Resultaten van een verklarende analyse van de kans op het binnen de eigen richting werken, cohort 1995-1996

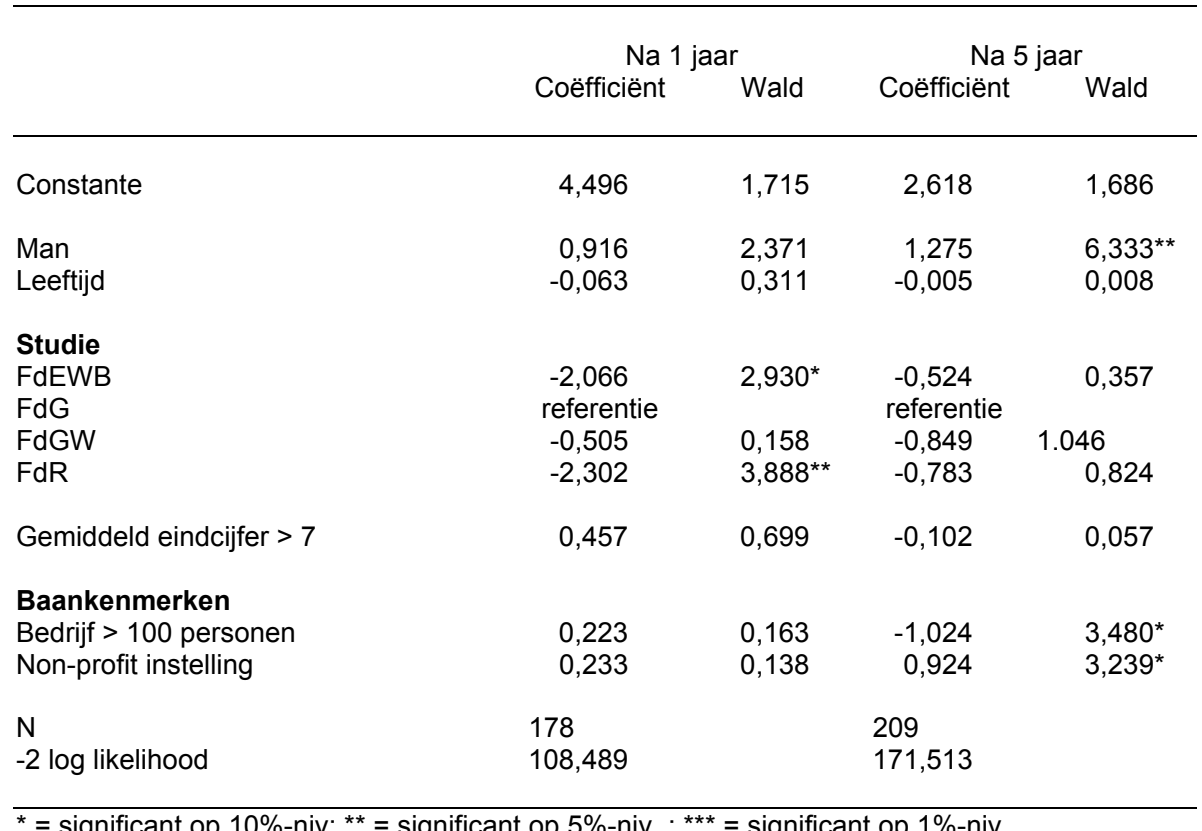

${ }^{*}=$ significant op 10\%-niv; ${ }^{* *}=$ significant op 5\%-niv. ; ${ }^{* *}=$ significant op $1 \%$-niv.

$\mathrm{Na}$ vijf jaar blijken geheel andere factoren een rol te spelen. Het is vooral het type werkgever dat bepaalt in hoeverre men binnen de eigen richting werkzaam is. De opleiding speelt geen significante rol meer. Alumni die in een groot bedrijf werkzaam zijn werken significant minder vaak in hun eigen richting. Grote bedrijven of instellingen bieden hun werknemers wellicht meer mogelijkheden om door te groeien in bijvoorbeeld managementfuncties. Alumni die emplooi gevonden hebben in nonprofit-instellingen zijn significant vaker in hun eigen richting werkzaam. Dit kan te maken hebben met het feit dat bijvoorbeeld universiteiten en ziekenhuizen nonprofitinstellingen zijn. Bovendien behoort bijvoorbeeld juist de ICT-sector niet tot de 
nonprofit-sector. We hebben in tabel 4.6 gezien dat veel UM'ers buiten hun eigen domein onder meer uitwijken naar ICT-functies.

\subsection{De gevolgen van het werken buiten het eigen beroependomein}

In deze paragraaf wordt gekeken naar de gevolgen van het buiten de eigen richting werkzaam zijn. Welke gevolgen heeft het voor de beloning? En zijn UM'ers binnen hun eigen beroependomein meer tevreden? Of juist niet? De tabellen 4.8 en 4.9 laten de relatie tussen de aansluiting naar richting en de beloning zien. Op grond van de theorie mag verwacht worden dat UM'ers binnen hun eigen beroependomein meer zullen verdienen dan daarbuiten. Immers: binnen het eigen domein is de aansluiting tussen verworven en vereiste kennis en vaardigheden beter. Verwacht mag worden dat door deze betere match ook de productiviteit en daarmee de beloning hoger zal zijn. Tabel 4.8 lijkt deze verwachting echter te logenstraffen. Eén jaar na afstuderen lijkt de beloning binnen en buiten het eigen domein elkaar nauwelijks te ontlopen. Binnen het eigen domein verdient de UM'er na eén jaar gemiddeld $€ 10,65$ per uur. Daarbuiten is dit met $€ 10,90$ iets hoger. Dit geringe verschil geldt vooral voor de economen, gezondheidswetenschappers en juristen. Voor de medici is het verschil opvallend groot. Binnen het eigen domein verdient de medicus gemiddeld $€ 10,92$ per uur. Daarbuiten is dit maar liefst $€ 13,09$. Hierbij dient echter rekening te worden gehouden met het feit dat medici na één jaar voor een groot deel nog in opleiding zijn. Dit effect speelt overigens ook bij de andere faculteiten een rol. Zo werken AIO's allemaal binnen hun eigen beroependomein. Deze goede aansluiting komt echter niet tot uiting in de beloning.

Tabel 4.8

Relatie tussen bruto uurloon in euro's en aansluiting naar richting na één jaar, cohort 1995-1996

\begin{tabular}{lcc} 
& Binnen eigen richting & Buiten eigen richting \\
\hline FdEWB & & \\
FdG & 11,26 & 11,45 \\
FdGW & 10,92 & 13,09 \\
FdR & 10,27 & 10,57 \\
Totaal & 10,09 & 10,13 \\
& 10,65 & 10,90 \\
\hline
\end{tabular}

\section{Bron: ROA}

Na vijf jaar werken veel minder UM'ers als AIO of zijn zij anderszins nog in opleiding. Toch lijkt het verschil in beloning tussen het eigen domein en daarbuiten toe te nemen. Tabel 4.9 laat zien dat na vijf jaar de UM'er binnen het eigen domein gemiddeld $€ 21,63$ verdient. Buiten het eigen domein is dit met $€ 22,50$ bijna 1 Euro meer. Dit verschil is vooral toe te schrijven aan de economen. Zij komen buiten hun eigen domein vaak in allerlei management- en ICT-functies terecht die goed worden beloond. In vergelijking met het beeld na één jaar is de situatie voor de medici daarentegen drastisch veranderd. Medici verdienen binnen hun eigen domein aanzienlijk meer dan daarbuiten. Het specifieke karakter van de opleiding en het daarop volgende traject begint dus na vijf jaar zijn vruchten af te werken. 
Tabel 4.9

Relatie tussen bruto uurloon in euro's en aansluiting naar richting na vijf jaar, cohort 1995-1996

Binnen eigen richting

Buiten eigen richting

\begin{tabular}{lll}
\hline & & \\
FdEWB & 24,49 & 27,04 \\
FdG & 21,00 & 15,20 \\
FdGW & 19,78 & 20,26 \\
FdR & 20,85 & 20,66 \\
Totaal & 21,63 & 22,50 \\
\hline
\end{tabular}

Bron: ROA

Uit de tabellen 4.8 en 4.9 lijkt de conclusie te mogen worden getrokken dat de aansluiting naar richting er voor de beloning niet zoveel toe doet. Sterker nog: met name voor economen lijkt de beloning buiten het eigen domein - zeker na vijf jaar hoger te zijn. Om alle factoren in hun onderlinge samenhang te kunnen bezien, zijn twee loonanalyses uitgevoerd van de beloning na één en na vijf jaar. De resultaten worden gepresenteerd in tabel 4.10. Aangezien in hoofdstuk 3 reeds uitgebreid aandacht is geschonken aan de determinanten van de beloning, richten we ons hier op het effect van het al dan niet buiten de eigen richting werkzaam zijn. Uit de tabel blijkt dat zowel na één als na vijf jaar het binnen het eigen vakgebied werkzaam zijn geen positief effect heeft op de beloning. Dit zou opnieuw kunnen betekenen dat de er niet echt sprake is van uitwijkgedrag, maar dat alumni bewust kiezen voor een baan die het best bij hen past. Dit resultaat sluit daarmee aan op hetgeen we eerder in dit hoofdstuk hebben gezien.

We hebben in dit hoofdstuk gezien dat UM'ers buiten hun eigen beroependomein zeker niet slechter af lijken te zijn dan in banen die goed aansluiten op de door hen gevolgde opleiding. Zij kiezen vaak om inhoudelijke redenen of vanwege het betere loopbaanperspectief voor een baan buiten het eigen domein. De beloning blijkt buiten het eigen domein zeker niet lager te zijn. De vraag is nu hoe UM'ers hier zelf tegenaan kijken. Zijn ze tevreden met hun huidige baan? En vooral: zijn UM'ers die werkzaam zijn in een baan die goed aansluit bij hun eigen richting meer of juist minder tevreden? In tabel 4.11 wordt gekeken naar de werksatisfactie van de UM'ers die een baan op WO-niveau gevonden hebben. UM'ers die op WO-niveau werkzaam zijn blijken over het algemeen zeer tevreden te zijn. Er blijkt weinig verschil te zijn tussen UM'ers die binnen en buiten hun eigen vakrichting werkzaam zijn. Van degenen die binnen het eigen domein emplooi hebben gevonden, is 84 procent (zeer) tevreden. Buiten het eigen domein is dit zelfs 88 procent. Dit beeld is bij alle faculteiten terug te vinden. Het verschil is het grootst bij de juristen. Binnen het eigen domein is 82 procent (zeer) tevreden; daarbuiten 93 procent. Dit is opnieuw een aanwijzing dat UM'ers heel bewust voor een baan buiten het eigen domein kiezen. 
Tabel 4.10

Resultaten van een verklarende analyse voor het bruto uurloon na één en vijf jaar, cohort 19951996

\begin{tabular}{|c|c|c|c|c|}
\hline & \multicolumn{2}{|c|}{$\mathrm{Na} 1$ jaar } & \multicolumn{2}{|c|}{$\mathrm{Na} 5$ jaar } \\
\hline & Coëfficiënt & t-waarde & Coëfficiënt & t-waarde \\
\hline Constante & 2,174 & $6,86^{\star * *}$ & 2,604 & $13,55^{\star * *}$ \\
\hline Man & $-0,049$ & $-0,97$ & 0,077 & 1,81 \\
\hline Leeftijd & 0,005 & 0,46 & 0,006 & 0,95 \\
\hline \multicolumn{5}{|l|}{ Samenstelling huishouden } \\
\hline Samenwonend met kinderen & 0,358 & $2,49^{* *}$ & 0,121 & $2,23^{* *}$ \\
\hline Samenwonend zonder kinderen & Referentie & & Referentie & \\
\hline Alleenstaand & 0,061 & 1,33 & 0,046 & 0,86 \\
\hline \multicolumn{5}{|l|}{ Studie } \\
\hline FdEWB & Referentie & & Referentie & \\
\hline $\mathrm{FdG}$ & $-0,053$ & $-0,68$ & $-0,075$ & $-1,03$ \\
\hline FdGW & $-0,182$ & $-2,53^{* *}$ & $-0,134$ & $-2,19^{\star *}$ \\
\hline FdR & $-0,103$ & $-1,58$ & $-0,140$ & $-2,53^{\star *}$ \\
\hline Gemiddeld eindcijfer $>7$ & $-0,002$ & $-0,05$ & 0,043 & 1,01 \\
\hline \multicolumn{5}{|l|}{ Dienstverband } \\
\hline Eigen bedrijf & $-0,262$ & $-0,873$ & 0,462 & $3,64^{* * *}$ \\
\hline Loondienst / freelance & Referentie & & Referentie & \\
\hline \multicolumn{5}{|l|}{ Baankenmerken } \\
\hline Werkzaam in eigen richting & $-0,092$ & $-1,24$ & $-0,037$ & $-0,67$ \\
\hline Parttime baan & 0,162 & $2,41^{* *}$ & 0,114 & $1,93^{*}$ \\
\hline Leidinggevende functie & 0,105 & $1,85^{*}$ & 0,080 & $1,84^{*}$ \\
\hline Bedrijf > 100 personen & 0,050 & 1,00 & 0,137 & $2,60^{* * *}$ \\
\hline Vaste aanstelling & 0,138 & $2,81^{* * *}$ & 0,123 & $2,18^{* *}$ \\
\hline Non-profit instelling & 0,051 & 0,98 & $-0,021$ & $-0,40$ \\
\hline $\mathrm{N}$ & 169 & & 209 & \\
\hline Gecorrigeerde R-kwadraat & 0,151 & & 0,201 & \\
\hline
\end{tabular}

${ }^{*}=$ significant op $10 \%$-niv; ${ }^{* *}=$ significant op $5 \%$-niv. $;{ }^{* *}=$ significant op $1 \%$-niv.

Tabel 4.11

Relatie tussen werksatisfactie en aansluiting naar richting, cohort 1995-1996 (percentage (zeer) tevreden met huidige baan)

\begin{tabular}{lrr}
\hline & & \\
FdEWB & 78 & 82 \\
FdG & 94 & 100 \\
FdGW & 85 & 86 \\
FdR & 82 & 93 \\
Totaal & 84 & 88 \\
\hline
\end{tabular}

Bron: ROA 
Aan de respondenten is ook gevraagd hun huidige werksituatie te confronteren met de verwachtingen die ze hadden bij aanvang van de opleiding aan de UM. In hoofdstuk 2 was al te zien dat de huidige werksituatie over het algemeen aan de verwachtingen voldoet. Uit tabel 2.11 bleek dat slechts 5 procent van de alumni uit het cohort 1995-1996 aangeeft dat de werksituatie (veel) slechter is dan verwacht. Tabel 4.12 laat zien dat voor degenen die een baan op WO-niveau werkzaam zijn, dit percentage nog lager is. Opvallender is dat het aantal UM'ers dat buiten zijn eigen richting werkzaam is en daarbij teleurgesteld is over zijn werksituatie te verwaarlozen is. Ook dit opvallend cijfer wijst erop dat alumni bewust voor een baan buiten hun eigen vakrichting hebben gekozen.

Tabel 4.12

Relatie tussen realisatie van verwachtingen en aansluiting naar richting, cohort 1995-1996 (percentage werksituatie (veel) slechter dan verwacht

\begin{tabular}{lcc} 
& Binnen eigen richting & Buiten eigen richting \\
\hline FdEWB & 2 & 0 \\
FdG & 4 & 0 \\
FdGW & 3 & 0 \\
FdR & 2 & 0 \\
Totaal & 3 & 0 \\
\hline
\end{tabular}

Bron: ROA

\subsection{Conclusie}

Centraal in dit hoofdstuk stond de vraag in hoeverre een loopbaanpad dat afwijkt van het 'reguliere' pad een goede optie kan zijn voor de alumni van de UM. In de analyses in dit hoofdstuk zijn tal van aanwijzingen terug te vinden dat dat inderdaad het geval is, voor zover het een baan op WO-niveau betreft. Zo zien we dat UM'ers steeds vaker buiten de eigen richting gaan werken naarmate de loopbaan vordert. $\mathrm{Na}$ één jaar is 10 procent van de UM'ers buiten de eigen richting werkzaam; na vijf jaar is dit gestegen tot 16 procent. Deze toename doet zich bij alle faculteiten voor. De toename is het sterkst onder de gezondheidswetenschappers. Juristen waaieren het vaakst uit over beroepen buiten het eigen domein. Medici zijn het vaakst werkzaam in een baan waarvoor de eigen of een verwante opleiding door de werkgever wordt vereist. Naarmate de loopbaan vordert neemt bovendien het aantal medici dat buiten het eigen beroependomein werkt nauwelijks toe.

Tien procent van de alumni blijkt na een start binnen het eigen domein te kiezen voor een baan waarvoor de werkgever niet expliciet de eigen of een verwante opleiding vereist. De groei van het aantal UM'ers dat, naarmate de loopbaan vordert, buiten de eigen richting werkzaam is moet vooral gezocht worden bij deze groep. Weliswaar is er een groep die vanaf de start van de loopbaan emplooi vindt buiten het eigen domein. Van deze groep keert echter meer dan de helft terug naar een baan binnen de eigen vakrichting. 
Veel UM'ers lijken een positieve keuze te maken voor een baan buiten het eigen vakgebied, Zo zijn het vaak inhoudelijke factoren die tot die keuze hebben geleid. Bijna 40 procent geeft aan liever buiten het eigen vakgebied te werken. Daarnaast geeft 16 procent aan het werk buiten het eigen vakgebied ook interessant te vinden. Een tweede belangrijk element wordt gevormd door factoren die te maken hebben met de arbeidsmarktpositie. Met name de betere carrièremogelijkheden (26 procent) worden hier vaak genoemd. Het niet kunnen vinden van een passende baan is daarentegen slechts voor 13 procent een bepalende factor. Ook privé-omstandigheden blijken voor relatief weinig UM'ers een drijfveer te zijn een baan buiten de eigen richting te zoeken. UM'ers komen daarbij relatief vaak in min of meer verwante beroepen terecht. De econoom wordt bijvoorbeeld commercieel medewerker en de gezondheidswetenschapper wordt (of blijft) therapeut of verpleegkundige. Daarnaast biedt de ICT-sector voor de UM'er een mogelijkheid zijn horizon te verbreden. Ook komen UM'ers na vijf jaar in managementfuncties terecht.

Een verklarende analyse laat zien dat één jaar na afstuderen het vooral de opleiding bleek te zijn die bepaalde of alumni al dan niet binnen hun eigen vakrichting werkzaam waren. Economen en juristen kwamen significant minder vaak in hun eigen richting terecht dan medici. Als gevolg van de meer beroepsgerichte kennis en vaardigheden en mogelijk als gevolg van de arbeidsmarktsituatie kwamen medici en gezondheidswetenschappers vaker in hun eigen beroependomein terecht. $\mathrm{Na}$ vijf jaar blijken geheel andere factoren een rol te spelen. Het is vooral het type werkgever dat bepaalt in hoeverre men binnen de eigen richting werkzaam is. De opleiding speelt geen significante rol meer. Alumni die in een groot bedrijf werkzaam zijn werken significant minder vaak in hun eigen richting. Grote bedrijven of instellingen bieden hun werknemers wellicht meer mogelijkheden om door te groeien in bijvoorbeeld managementfuncties. Alumni die emplooi gevonden hebben in nonprofit-instellingen zijn significant vaker in hun eigen richting werkzaam. Dit kan te maken hebben met het feit dat bijvoorbeeld universiteiten en ziekenhuizen nonprofitinstellingen zijn. Een verklarende loonanalyse laat zien dat UM'ers buiten hun eigen domein zeker niet minder verdienen dan banen die goed aansluiten op de gevolgde opleidingsrichting.

Tenslotte blijkt er weinig verschil te zijn in werksatisfactie tussen UM'ers die binnen en buiten hun eigen vakrichting werkzaam zijn. Van degenen die binnen het eigen domein emplooi hebben gevonden, is 84 procent (zeer) tevreden met de huidige baan. Buiten het eigen domein is dit zelfs 88 procent. Dit beeld is bij alle faculteiten terug te vinden. Het verschil is het grootst bij de juristen. Binnen het eigen domein is 82 procent (zeer) tevreden; daarbuiten 93 procent. Daarnaast is het aantal UM'ers dat buiten zijn eigen richting werkzaam is en daarbij teleurgesteld is over zijn werksituatie te verwaarlozen. Deze tevredenheid kan misschien wel gezien worden als de meest krachtige aanwijzing dat het afwijken van het reguliere loopbaanpad een reële optie is voor UM'ers. 